\title{
Aerosolized Hydrogen Peroxide Decontamination of N95 Respirators, with Fit-Testing and Virologic Confirmation of Suitability for Re-Use During the COVID-19 Pandemic
}

T. Hans Derr ${ }^{1 * \wedge}$, Melissa A. James ${ }^{2 \wedge}$, Chad V. Kuny ${ }^{4,8 \wedge}$, Devanshi Patel ${ }^{6,8}$, Prem P. Kandel ${ }^{5}$, Cassandra Field $^{6,8}$, Matthew D. Beckman ${ }^{7}$, Kevin L. Hockett ${ }^{5,8}$, Mark A. Bates ${ }^{3}$, Troy C. Sutton $^{6,8}$, Moriah Szpara ${ }^{4,8 *}$

$\wedge$ co-first-authors

${ }^{1}$ Environmental Health and Safety; ${ }^{2}$ Animal Resource Program, ${ }^{3}$ Occupational Medicine Program, and ${ }^{4}$ Departments of Biology, Biochemistry and Molecular Biology, ${ }^{5}$ Plant Pathology and Environmental Microbiology, ${ }^{6}$ Veterinary and Biomedical Sciences, ${ }^{7}$ Statistics, ${ }^{8}$ Center for Infectious Disease Dynamics, and the Huck Institutes of the Life Sciences, Pennsylvania State University, University Park, Pennsylvania 16802, USA

\section{*Co-Corresponding Authors}

Moriah L. Szpara, PhD

Depts. of Biology, and Biochemistry \&

Molecular Biology

The Huck Institutes of the Life Sciences

Pennsylvania State University

W-208 Millennium Science Complex

(MSC)

University Park, PA 16802 USA

Phone: 814-867-0008

Email: moriah@psu.edu
T. Hans Derr, CIH

Manager, Health \& Environmental

Programs

Environmental Health \& Safety

Pennsylvania State University

6B Eisenhower Deck

University Park, PA 16802

Phone: 814-863-3834

Email: thd12@psu.edu

\section{Author emails:}

Mark A. Bates: mxb20@psu.edu

Matthew D. Beckman: mdb268@psu.edu

T. Hans Derr: thd12@psu.edu

Cassandra Field: cif5202@psu.edu

Kevin L. Hockett: klh450@psu.edu

Melissa A. James: maj22@psu.edu
Prem Kandel: puk155@psu.edu Chad V. Kuny: cvk108@psu.edu Devanshi Patel: drp5323@psu.edu Troy C. Sutton: tcs38@psu.edu Moriah L. Szpara: $\underline{\text { moriah@psu.edu }}$ 
medRxiv preprint doi: https://doi.org/10.1101/2020.04.17.20068577; this version posted December 24, 2020. The copyright holder for this preprint (which was not certified by peer review) is the author/funder, who has granted medRxiv a license to display the preprint in perpetuity.

It is made available under a CC-BY-NC-ND 4.0 International license.

Derr et al, preprint for medRxiv, 2020

N95 aHP decontamination study

\section{Abstract}

2 In response to the current demand for N95 respirators by healthcare workers responding to the

3 COVID-19 pandemic, we evaluated decontamination of N95 respirators using a low

4 concentration aerosolized hydrogen peroxide (aHP) system. This system dispenses a consistent

5 atomized spray of micron-sized, low concentration, hydrogen peroxide $\left(\mathrm{H}_{2} \mathrm{O}_{2}\right)$ particles over a

6 treatment cycle. Multiple N95 respirator models were subjected to ten or more cycles of

7 respirator decontamination, and masks were periodically assessed for qualitative and quantitative

8 fit testing to verify respirator integrity. In parallel, we assessed the ability of aHP treatment to

9 inactivate multiple viruses absorbed onto masks, including phi6 bacteriophage, HSV-1, CVB3,

10 and SARS-CoV-2. Given that SARS-CoV-2 is transmitted via expired respiratory droplets and

11 aerosols, it is critical to address respirator safety for reuse. This study provided experimental

12 validation of a suitable aHP treatment process that decontaminates the respirators while

13 maintaining N95 function. After ten rounds of aHP treatment, respirators passed N95 filtration

14 efficiency testing. Virus inactivation by aHP was comparable to the sterilization of commercial

15 spore-based biological indicators. These data demonstrate that the aHP process is effective, on

16 the basis of zero failure rate on fit-testing of respirators, effective decontamination of multiple

17 virus species including SARS-CoV-2, successful sterilization of bacterial spores, and filtration

18 efficiency maintained at or greater than $95 \%$. Collectively, these studies support the use of

19 specific aHP decontamination protocol that permits safe reuse of N95 respirators by healthcare

20 providers.

\section{Importance}

23 The ongoing COVID-19 pandemic has led to unprecedented pressure on healthcare and research

24 facilities to provide adequate personal protective equipment. Given that the current pandemic is

25 caused by a respiratory viral pathogen, the availability of highly protective respirator facepieces

26 is critical to limit inhalation of this virus. While respirator facepieces were designed for single-

27 use and disposal, the pandemic has increased overall demand for N95 respirators, and

28 corresponding manufacturing and supply chain limitations have necessitated the safe reuse of

29 respirators when necessary. The biosafety level 3 (BSL3) facility used in this study regularly 
medRxiv preprint doi: https://doi.org/10.1101/2020.04.17.20068577; this version posted December 24, 2020. The copyright holder for this preprint (which was not certified by peer review) is the author/funder, who has granted medRxiv a license to display the preprint in perpetuity.

It is made available under a CC-BY-NC-ND 4.0 International license.

Derr et al, preprint for medRxiv, 2020

N95 aHP decontamination study

30 utilizes aerosolized hydrogen peroxide (aHP) to decontaminate equipment and spaces. We

31 repurposed this technology for N95 respirator decontamination during the COVID-19 pandemic.

32 Results from virus inactivation, biological indicators, respirator fit testing, and filtration

33 efficiency testing all indicated that the process was effective at rendering N95 respirator safe for

34 reuse.

Keywords:

37 N95 respirators, decontamination, aerosolized hydrogen peroxide, COVID-19, SARS-CoV2,

38 virologic testing, virus, fit-testing, disinfection, sterilization, Pathogo ${ }^{\mathrm{TM}} \mathrm{Curis}^{\circledR}$

\section{Abbreviations:}

41 aHP, aerosolized hydrogen peroxide $\left(\mathrm{H}_{2} \mathrm{O}_{2}\right)$; BSL, biosafety level; COVID-19, coronavirus

42 disease 2019; CVB3, coxsackievirus B3; $\mathrm{H}_{2} \mathrm{O}_{2}$, hydrogen peroxide; HPM, hydrogen peroxide

43 vapor monitor; HSV-1, herpes simplex virus 1; phi6, Pseudomonas phi6 bacteriophage; OSHA,

44 Occupational Safety and Health Administration; QLFT, qualitative fit test; QNFT, quantitative

45 fit-test; SARS-CoV-2, severe acute respiratory syndrome coronavirus 2; VPHP, Vapor-phase

46 hydrogen peroxide.

\section{Introduction}

48 In response to the ongoing severe acute respiratory syndrome coronavirus 2 (SARS-CoV-2)

49 pandemic, there is a shortage of personal protective equipment (PPE). In healthcare settings, the

50 need for PPE is critical to protect frontline healthcare providers from infection, and to reduce

51 cross-contamination between patients with coronavirus disease 2019 (COVID-19) and other

52 uninfected patients. In healthcare settings, N95 respirators (including surgical N95 respirators)

53 are used to provide protection from airborne infectious particles. The N95 terminology refers to

54 the ability to block at least 95 percent of the most penetrating particle sizes $(0.1-0.3$ micron $)$.

55 Proper use of N95 respirators requires qualitative fit-testing (QLFT) or quantitative fit-testing

56 (QNFT), which are designed to ensure a tight face-to-respirator seal for each specific wearer's

57 face. 
medRxiv preprint doi: https://doi.org/10.1101/2020.04.17.20068577; this version posted December 24, 2020. The copyright holder for this

preprint (which was not certified by peer review) is the author/funder, who has granted medRxiv a license to display the preprint in perpetuity.

It is made available under a CC-BY-NC-ND 4.0 International license .

Derr et al, preprint for medRxiv, 2020

N95 aHP decontamination study

58 The current shortage of N95 respirators is due to limitations on the required raw materials,

59 limited capacity to manufacture the masks, and the ability of supply and distribution chains to

60 handle increased global demand. For this reason, researchers have sought to demonstrate the

61 potential for decontamination and reuse of existing N95 respirators. Standardized procedures are

62 well-established for the sterilization and reuse of medical equipment, such as autoclaving, steam

63 treatment, and chemical inactivation (e.g. bleach) (1). Sterilization of most medical equipment is

64 verified using spore-based biological indicators (2). Unlike most hospital equipment (e.g. steel,

65 metal, plastic) or fabrics (e.g. blankets) for which standardized sterilization methods exist (1),

66 N95 respirators are generally not intended for re-use (3). Thus many of the standard sterilization

67 approaches deform, damage, or destroy the integrity of N95 respirator fabric, nosepiece

68 materials, or elastic straps $(4,5)$. Hydrogen peroxide $\left(\mathrm{H}_{2} \mathrm{O}_{2}\right)$-based methods have been

69 successfully adapted for use in decontamination of N95 respirators, with indications that these

70 methods are less damaging than other decontamination methods (e.g. chemical or steam), and

71 can penetrate the densely-woven fabric of respirator facepieces $(4,6)$. In addition, the viricidal

72 capability of $\mathrm{H}_{2} \mathrm{O}_{2}$ sterilization methods has been previously demonstrated (7-9). Vapor-phase

$73 \mathrm{H}_{2} \mathrm{O}_{2}$ methods (e.g. "VHP" and other patented methods) have been used to decontaminate N95

74 respirators and were granted U.S. Food and Drug Administration (FDA) "Emergency Use

75 Authorization" (EUA) for healthcare use; however, these methods employ high concentrations of

76 hydrogen peroxide (30-70\%) and elevated temperature to achieve vaporization. Vapor-phase

$77 \mathrm{H}_{2} \mathrm{O}_{2}$ (VPHP) methods at these concentrations pose increased health risks to decontamination

78 personnel, and combined with elevated temperature, can result in notable respirator material

79 decay (10). Historical aerosolized $\mathrm{H}_{2} \mathrm{O}_{2}$ (aHP) methods utilize lower peroxide concentrations (5-

$806 \%$ ) with silver ions and other antimicrobial agents, activated aerosolization via plasma, nozzle

81 pressure, or ultrasound, with similar limitations to VPHP methods (11-15). These methods have

82 not received strong comparative support in U.S. markets due to lower sterilization effectiveness

$83(13,15-21)$. Therefore, we utilized a recently developed aHP method (i.e. the Pathogo ${ }^{\text {TM }}$ Curis $^{\circledR}$

84 system), which dispenses a low concentration hydrogen peroxide solution through a precision

85 adjustable nozzle. The unit design and decontamination process characteristics allow consistent

86 distribution of disinfectant over time and effective decontamination of space and materials with

87 reduced health risk to personnel (22). 
medRxiv preprint doi: https://doi.org/10.1101/2020.04.17.20068577; this version posted December 24, 2020. The copyright holder for this preprint (which was not certified by peer review) is the author/funder, who has granted medRxiv a license to display the preprint in perpetuity.

It is made available under a CC-BY-NC-ND 4.0 International license .

Derr et al, preprint for medRxiv, 2020

N95 aHP decontamination study

88 At present, respirator manufacturers have not approved protocols for N95 respirator

89 decontamination (3). To address imminent pandemic needs, healthcare settings are referencing

90 U.S. Centers for Disease Control and Prevention (CDC) guidelines on provisional N95 respirator

91 decontamination and reuse (22). Battelle Memorial Institute of Columbus, Ohio, received FDA

92 EUA status for an N95 decontamination protocol using a VHP method, based on a prior study

93 addressing the potential for respirator reuse in emergency scenarios $(4,23)$. This study included

94 evaluation of respirator structure, filtration, and manikin fit-testing, and used bacterial spore-

95 based biological indicators to demonstrate effective sterilization (4); however, viral inactivation

96 testing and respirator fit on live subjects were not performed. Given the current pandemic entails

97 a respiratory viral pathogen, several decontamination protocols are being actively investigated at

98 research universities and medical centers (24-31).

99 Given the reduced personnel health risks of using aHP, we assessed the ability of an aHP

100 decontamination protocol to achieve viral and microbial sterilization of N95 respirators, while

101 preserving respirator fit and integrity over multiple treatment cycles. Several respirator facepiece

102 types, representing those in use by local healthcare and research personnel, were included, and

103 decontamination was tested using multiple viral surrogates representing the structure,

104 characteristics, and environmental resistance of the SARS-CoV-2 pathogen. These surrogates

105 included Pseudomonas phi6 bacteriophage (phi6), herpes simplex virus 1 (HSV-1), and

106 coxsackievirus B3 (CVB3). After establishing successful decontamination of these surrogate

107 virus species, we further demonstrated decontamination of infectious SARS-CoV-2 virus spotted

108 on to respirators. Throughout the process, Geobacillus stearothermophilus spore-based

109 biological indicators were used to verify effectiveness of decontamination. Testing of virus

110 inactivation utilized plaque or tissue culture infectious dose 50\% (TCID50) assays to detect the

111 partial inactivation of viruses by drying or desiccation onto respirator surfaces, and their

112 subsequent decontamination by aHP. Fitness of respirators for reuse was assessed by qualitative

113 and quantitative respirator fit testing of subjects using respirators subjected to multiple

114 decontamination cycles. Real-time measurement and separate diffusion sampler analyses of

115 hydrogen peroxide were used to monitor aHP levels associated with decontamination and

116 subsequent decomposition of aHP through drying prior to fit testing and reuse. 
medRxiv preprint doi: https://doi.org/10.1101/2020.04.17.20068577; this version posted December 24, 2020. The copyright holder for this preprint (which was not certified by peer review) is the author/funder, who has granted medRxiv a license to display the preprint in perpetuity.

It is made available under a CC-BY-NC-ND 4.0 International license .

Derr et al, preprint for medRxiv, 2020

N95 aHP decontamination study

\section{Methods}

\section{Decontamination Facility}

119 The decontamination process was carried out in the Eva J. Pell Laboratory for Advanced

120 Biological Research at The Pennsylvania State University, University Park campus. This facility

121 is a purpose-built BSL3 enhanced facility, and all required approvals were obtained from the

122 Institutional Biosafety Committee (IBC) for work involving viruses, as described below.

124 The primary decontamination process was performed within in an approximate 1,700 cubic feet

125 sealed Preparation Room (Prep Room), followed by additional virus inactivation testing with

126 SARS-CoV-2 in a separate, nearby 1,840 cubic feet Prep Room. Procedures and personal

127 protective equipment (PPE) suitable for the viruses and materials in use were strictly observed in

128 this biosafety level 3 (BSL-3) facility, which has consistently maintained institutional, CDC, and

129 USDA approval for work with risk group 3 pathogens since its commissioning in 2014.

\section{Decontamination Preparation}

131 Respirators for decontamination were staged on a portable metal rack located centrally in the

132 Prep Room (Supplementary Figure 1). Filtered and conditioned air is supplied to the Prep Room

133 and the air exhausted from the room is HEPA-filtered. Bubble-tight dampers (Camfil Farr ${ }^{\circledR}$ ) were

134 operated to seal both the supply and exhaust air from associated ductwork during the

135 decontamination cycle. The Curis ${ }^{\circledR}$ decontamination unit (Supplementary Figure 2) was

136 programmed, equipment positioned, and the room doors sealed using polyethylene sheeting and

137 non-porous adhesive tape (Supplementary Figure 3).

\section{Decontamination Process}

139 The Curis ${ }^{\circledR}$ decontamination unit programming method utilizes room size to establish the

140 baseline parameters for charge (initial aHP dispensing) and intermittent aHP pulse periods. Once

141 the user inputs the room's cubic volume or dimensions, the unit calculates the appropriate

142 duration of the charge and pulse periods. Unit operation includes a user-defined dwell period

143 (when no further aHP is introduced), at closure of the pulse period. Aeration is initiated

144 following the dwell period (room seals are broken and ventilation resumed). The standard 
medRxiv preprint doi: https://doi.org/10.1101/2020.04.17.20068577; this version posted December 24, 2020. The copyright holder for this

preprint (which was not certified by peer review) is the author/funder, who has granted medRxiv a license to display the preprint in perpetuity.

It is made available under a CC-BY-NC-ND 4.0 International license .

Derr et al, preprint for medRxiv, 2020

N95 aHP decontamination study

145 aeration period is 3 hours, unless an auxiliary scavenging system is attached, or other space

146 aeration system is utilized.

147 Under air-tight/sealed conditions with neutral pressurization for the $1700 \mathrm{ft}^{3}$ room used,

148 programming included an 11-minute, 43-second continuous charge of aHP $\left(7 \% \mathrm{H}_{2} \mathrm{O}_{2}\right.$;

149 Curoxide $^{\circledR}$ ), followed by six (6) pulse charges evenly spaced over 30 minutes to maintain $\mathrm{H}_{2} \mathrm{O}_{2}$

150 concentrations. To account for absorption of aHP into porous materials in the decontamination

151 space (e.g. N95 respirators), a 30-40\% increase in these default settings was initially used, as is

152 typically recommended by the manufacturer. Additionally, to ensure adequate contact time of

153 disinfectant to the treated surfaces, a dwell period is recommended after the continuous and pulse

154 charge periods (decontamination phase) and prior to the aeration phase. Based on initial results,

155 adjustments in the charge, pulse, and dwell periods were conducted to establish effectiveness of

156 the overall decontamination process (Tables 3-4).

157 After completion of the decontamination phase, an aeration or dissipation phase was initiated by

158 removing fixed room seals and opening exhaust dampers for up to 2-hour periods, with the room

159 under slight vacuum (0.18-0.19” W.G.). Adjustments were made to room air exchange rate

160 during aeration to efficiently dissipate detectable $\mathrm{H}_{2} \mathrm{O}_{2}$ from respirator facepieces. At cycle 5,

161 final parameters were established to include an aeration exhaust rate greater than or equal to 35

162 air changes/hour, with make-up air supplied by outdoor air. Following this phase, and after room

$163 \mathrm{H}_{2} \mathrm{O}_{2}$ concentration was measured at less than $1 \mathrm{ppm}$, the respirator-holding rack was either

164 retained under ventilation or transferred to a separate room (referred to as the "Finishing Room")

165 with an HVAC air supply curtain to further dry and decompose residual aHP from respirator

166 facepieces to less than $1 \mathrm{ppm}_{2} \mathrm{O}_{2}(8,9)$.

167 For respirators subjected to repeated rounds of decontamination as part of this study,

168 decontamination cycles were conducted repetitively from staging through drying. In order to be

169 considered "dry" or ready for the next cycle, the interior and exterior respirator surfaces were

170 monitored using a calibrated, hand-held real-time $\mathrm{H}_{2} \mathrm{O}_{2}$ monitor (ATI PortaSens II), and $\mathrm{H}_{2} \mathrm{O}_{2}$

171 concentrations were required to measure less than $1 \mathrm{ppm}$ prior to repeating a cycle, or prior to

172 transport for subsequent respirator fit-testing or virus inactivation analysis. The U.S. Department

173 of Labor/Occupational Safety and Health Administration (OSHA) and the American Conference

174 of Governmental Industrial Hygienists (ACGIH) have established or adopted an eight-hour time- 
medRxiv preprint doi: https://doi.org/10.1101/2020.04.17.20068577; this version posted December 24, 2020. The copyright holder for this

preprint (which was not certified by peer review) is the author/funder, who has granted medRxiv a license to display the preprint in perpetuity.

It is made available under a CC-BY-NC-ND 4.0 International license .

Derr et al, preprint for medRxiv, 2020

N95 aHP decontamination study

175 weighted average (TWA) occupational permissible exposure limit (PEL) to hydrogen peroxide

176 of $1 \mathrm{ppm}(32,33)$. Though researchers and fit-test subjects were not anticipated to experience

177 this eight-hour exposure level, $1 \mathrm{ppm} \mathrm{H}_{2} \mathrm{O}_{2}$ concentration was used as a safety threshold for

178 room entry, sealing respirators for transport, and re-use by study participants.

179 Since this study did not involve respirator re-use in actual hospital or clinical settings for safety 180 reasons, the treated/dried respirators were subjected to manual stress as a proxy for the physical

181 wear during use that may challenge subsequent fit integrity. To simulate this stress condition,

182 each respirator was flexed bi-directionally and each band was stretched twice to a hold position 183 similar to respirator donning, prior to re-start of the next decontamination cycle.

\section{Spore-based Biological Indicators}

185 Biological indicator $(\mathrm{BI})$ spore discs $\left(\right.$ Steris Spordex $\left.{ }^{\circledR}\right)$ inoculated with Geobacillus

186 stearothermophilus (ATCC ${ }^{\circledR} 7953$; mean spore count $2.4 \times 10^{5}$ ) were used to verify successful 187 decontamination (34). BIs (between 6 and 12 per cycle) enclosed in Tyvek/glassine envelopes

188 were placed throughout the room for each decontamination cycle. These were located behind or 189 beneath equipment and surfaces, on the portable metal rack holding respirators, and either on or 190 enclosed within the respirators themselves (Supplementary Figure 4). BIs were collected after

191 each cycle, each spore disc transferred from glassine/Tyvek envelopes to tryptic soy broth

192 (Spordex ${ }^{\circledR}$ Culture Media), incubated at $55^{\circ} \mathrm{C}$, and analyzed after 7 days as an indicator of

193 effective decontamination (Supplementary Figure 5).

194 Chemical Indicators of $\mathbf{H}_{2} \mathbf{O}_{2}$

195 Chemical indicator strips (Steris Steraffirm ${ }^{\circledR}$ or Curis ${ }^{\circledR}$ System Hydrogen Peroxide Test Strips)

196 (between 1 and 4 total per cycle) were placed in various locations throughout the Prep Room to

197 indicate the presence of $\mathrm{H}_{2} \mathrm{O}_{2}$, supporting successful decontamination.

\section{Real-Time Hydrogen Peroxide Monitoring}

199 The portable ATI PortaSens II detector (PortaSens) was used to measure $\mathrm{H}_{2} \mathrm{O}_{2}$ levels both within 200 and outside the Prep Room during the decontamination process. Hydrogen peroxide

201 concentrations were measured at respirator surfaces, and necessarily reduced to less than $1 \mathrm{ppm}$ 202 prior to handling or sealing for transportation to designated tissue culture rooms. During the 
medRxiv preprint doi: https://doi.org/10.1101/2020.04.17.20068577; this version posted December 24, 2020. The copyright holder for this preprint (which was not certified by peer review) is the author/funder, who has granted medRxiv a license to display the preprint in perpetuity.

It is made available under a CC-BY-NC-ND 4.0 International license.

Derr et al, preprint for medRxiv, 2020

N95 aHP decontamination study

203 charge and pulse periods of decontamination, real-time instantaneous sampling was conducted

204 through a sealable wall port (designed for sterilizer tubing) into the Prep Room. The PortaSens

205 was also used to monitor Prep Room concentrations at the start of the aeration phase, and to

206 verify concentrations were reduced to less than $1 \mathrm{ppm}$ for safe re-entry to the room (without

207 respiratory protection). In addition, $\mathrm{H}_{2} \mathrm{O}_{2}$ concentrations were also monitored within the adjacent

208 corridor along the Prep Room door seal (see Supplementary Figure 3), to assess $\mathrm{H}_{2} \mathrm{O}_{2}$ leakage.

209 Hydrogen Peroxide Diffusion Samplers $\left(\mathbf{H}_{2} \mathbf{O}_{2}\right.$ Vapor Monitors)

210 Diffusion samplers, also known as hydrogen peroxide vapor monitors (HPMs) were utilized to

211 monitor long-duration $\mathrm{H}_{2} \mathrm{O}_{2}$ leakage outside the Prep Room entry (outside containment or OC),

212 on research personnel during decontamination activities (breathing zone samples, clipped to

213 lapel-collar), and within sealed respirator transport containers (prior to fit-testing) to verify that

$214 \mathrm{H}_{2} \mathrm{O}_{2}$ concentrations remained less than $1 \mathrm{ppm}$ throughout transport and fit-testing. Once the

215 decontamination process was standardized with specific room ventilation parameters, ongoing

216 personnel monitoring was discontinued.

217 HPM sampler analysis was conducted by Advanced Chemical Sensors, Inc. (ACS) of

218 Longwood, FL utilizing an ACS HP-10 hydrogen peroxide vapor monitor, via modified OSHA

219 Method VI-6 (colorimetric analysis). Analysis was subcontracted and completed by laboratories

220 participating in the American Industrial Hygiene Association (AIHA) Laboratory Accreditation

221 Program. The AIHA is an ISO/IEC 17025 accrediting body $(35,36)$.

\section{Respirator Selection for the Study}

223 The N95 respirator facepiece models examined in this study represent those frequently used at

224 Penn State or within the Penn State Health system. Six models were selected, with a range of

225 characteristics, including those identified as surgical N95 respirators (no exhalation valve to

226 maintain sterile field), and non-surgical N95 respirators with an exhalation valve. These

227 characteristics are summarized in Table 1 and illustrated visually in Supplementary Figure 6.

228 Respirator models were required to be successfully fitted by test subjects. Fit-testing participants

229 included experienced test subjects and/or administrators. Several respirator models were

230 qualitatively fit-tested (QLFT) using Occupational Safety and Health Administration (OSHA) fit

231 test protocols (saccharine challenge) described in the OSHA Respiratory Protection Standard (29 
medRxiv preprint doi: https://doi.org/10.1101/2020.04.17.20068577; this version posted December 24, 2020. The copyright holder for this preprint (which was not certified by peer review) is the author/funder, who has granted medRxiv a license to display the preprint in perpetuity.

It is made available under a CC-BY-NC-ND 4.0 International license .

Derr et al, preprint for medRxiv, 2020

N95 aHP decontamination study

232 CFR 1910.134) (37). This included standard exercises to challenge respirator fit, over an

233 approximate 8 minute, 30 second period. Additionally, quantitative fit-testing (QNFT) was

234 conducted using OSHA protocol requirements with a T.S.I, Inc. PortaCount Pro+ Model 8038

235 Fit Tester. This latter method employs condensation nucleus or particle counting technology

236 (CNC or CPC) to measure aerosol concentration outside and inside the facepiece to determine a

237 user fit-factor (38).

\section{Sample Size and Acceptance Criteria for Fit-Test Reliability}

239 Study design for the QLFT endpoint was intended to rigorously evaluate user respirator to

240 facepiece seal with 3M 8511 respirators, while also providing representative feasibility data for

241 the other respirator models (Table 1). Sample sizes associated with additional respirator models

242 in Table 1 (i.e., those other than 3M 8511) were not derived to meet a statistical endpoint. The

243 3M 8511 respirators used in this study were procured and collected by Penn State from 2006 to

244 2009. As is common with stockpiled supplies, the manufacturer's 5-year expiration date had

245 been exceeded prior to this study for the 3M 8511 respirators. All other respirator models (Table

246 1) were tested prior to their expiration date. All respirator models were unused prior to this study.

247 Acceptance criteria for 3M 8511 respirators required a minimum sample of 59 facepieces with

248 no failures during QLFT in order to conclude with $95 \%$ confidence that at least $95 \%$ of $3 \mathrm{M} 8511$

249 respirators maintain fit integrity after repeated use and decontamination. A total of seventy-seven

2503 M 8511 respirators were available for study purposes. A small number of these, as well as other

251 respirator models were allocated for QNFT and virology testing subsequent to fit testing rounds.

252 QNFT provided metric data related to fit factor, safety margin, and objective evaluation of the

253 QLFT process to detect user fatigue (e.g., false negative for saccharine challenge). The 63

254 remaining 3M 8511 respirators provided sufficient sample size for evaluation against our

255 acceptance criteria based on QLFT.

\section{Respirator Fit-Testing}

257 Prior to decontamination, respirators were labeled with a unique identifier. After

258 decontamination, a hash mark was placed on the lower elastic band of each respirator to identify

259 the round(s) of decontamination completed (Supplementary Figure 7). At the conclusion of aHP

260 decontamination, respirators were confirmed to have less than 1 ppm $\mathrm{H}_{2} \mathrm{O}_{2}$ before transfer into 
medRxiv preprint doi: https://doi.org/10.1101/2020.04.17.20068577; this version posted December 24, 2020. The copyright holder for this preprint (which was not certified by peer review) is the author/funder, who has granted medRxiv a license to display the preprint in perpetuity.

It is made available under a CC-BY-NC-ND 4.0 International license .

Derr et al, preprint for medRxiv, 2020

N95 aHP decontamination study

261 sealed plastic containers for transport to the fit-testing facility. Since the study was conducted

262 during the COVID-19 pandemic, social distancing conditions limited the use of multiple test

263 subjects, therefore, two respirator fit-test subjects were selected (one male, one female) for fit-

264 testing of selected respirators. All 3M 8511 respirators were subjected to QLFT on the first, fifth,

265 and tenth rounds of decontamination. In order to continually monitor QLFT test outcomes on the

266 same facepieces over the course of sequential cycles of decontamination, a small number of

267 respirators per model were allocated for QNFT during each round of fit testing. Based on

268 historical studies by the QNFT device and respirator manufacturers, N95 respirators have

269 maximum breakthrough for particle sizes of $0.1-0.3$ micron. Particles smaller or larger than this

270 range have increased filtration efficiency (greater than 95\%). QNFT fit testing of N95 respirators

271 therefore focuses on measuring this maximum penetration size range, to ensure that detectable

272 leakage is due to facepiece seal leakage. OSHA has established a minimum QNFT passing fit

273 factor of 100 for half-face respirators (including N95s or filtering-facepiece respirators) (37).

274 The QNFT instrument manufacturer has established a maximum quantifiable fit factor of 200, as

275 limited by measurement reliability and particle counting factors. QNFT fit factors equal to or

276 exceeding 200 are therefore reported as 200(+). The reported QNFT data were utilized to verify

277 successful fit reported by QLFT.

278 Respirators subjected to QNFT (with metal grommet/probe installed) could not be reused for fit

279 testing. These were repurposed for subsequent virus inactivation testing in order to conserve

280 overall respirator use.

\section{$281 \quad$ NIOSH Filtration Efficiency Testing}

282 To determine whether N95 respirators used in this study experienced filtration media breakdown 283 as a result of sequential aHP disinfection cycles, several respirators were sent for independent

284 laboratory analysis. These included eight 3M 8511 respirators subjected to cyclic aHP treatment

285 and intermittent fit-testing, and two additional unused, untreated 3M 8511 respirators. Respirator

286 filtration efficiency testing was performed by ICS Laboratories, Inc. (ICS) of Brunswick, Ohio.

287 ICS is one of two firms in the U.S. authorized by the National Institute for Occupational Safety

288 and Health (NIOSH) to perform respirator certification or re-certification.

289 An abbreviated "short-cycle" filtration efficiency verification test was conducted using the

290 NIOSH Standard Test Procedure TEB-APR-STEP-0059 (39), which is summarized below. The 
medRxiv preprint doi: https://doi.org/10.1101/2020.04.17.20068577; this version posted December 24, 2020. The copyright holder for this preprint (which was not certified by peer review) is the author/funder, who has granted medRxiv a license to display the preprint in perpetuity.

It is made available under a CC-BY-NC-ND 4.0 International license.

Derr et al, preprint for medRxiv, 2020

N95 aHP decontamination study

291 standard test protocol includes initial respirator conditioning at $85+/-5 \%$ relative humidity

$292(\% \mathrm{RH})$ and $38+/-2^{\circ} \mathrm{C}$ for 25 hours prior to testing. This conditioning was intended to reflect

293 active moisture load created by the respirator user. Following sealing of the respirator exhalation

294 valve, and placing into the test instrument, full-load testing was performed. This testing included

295 respirator challenge using 200 milligrams sodium chloride aerosol (mean count particle size

296 distribution verified as $0.075+/-0.020$ microns, with geometric standard deviation not exceeding

297 1.86). Sodium chloride aerosol was neutralized to a "Boltzman equilibrium state" $\left(25+/-5^{\circ} \mathrm{C}, 30\right.$

$298+/-10 \%$ relative humidity), and introduced at an airflow rate of $85+/-4$ liters per minute, with

299 periodic check and adjustment to maintain this flowrate. Instrumental analysis was conducted

300 using a T.S.I Automated Filter Tester Model 8130A. Recorded data included flow rate,

301 resistance, penetration, maximum penetration and filtration efficiency.

302 The test protocol establishes the means for ensuring that the particulate filtering efficiency of

303 N95 series filters used on non-powered respirators submitted for Approval, Extension of

304 Approval, or examined during Certified Product Audits, meets the minimum certification

305 standards set forth in 42 CFR, Part 84, Subpart K, $§ 84.181$.

\section{Virus Inoculation and Titration}

307 Viruses used here included herpes simplex virus 1 (HSV-1) strain F, coxsackievirus B3 (CVB3), 308 Pseudomonas phi6 bacteriophage (phi6) and SARS-CoV-2 isolate USA-WA1/2020. The key

309 characteristics of these viruses are summarized in Table 2. All virus-inoculated materials were

310 handled in accordance with the biosafety level (BSL) specified for that virus (see Table 2). In all

311 numbered aHP cycles (Table 4), the respirators used for virus inactivation testing had been

312 subjected to preceding total number of aHP cycles - e.g. respirators used for viral testing in aHP

313 cycle \#6 had been already been subjected to 5 prior aHP cycles. In the case of the aHP cycles

314 labeled "Post" (i.e. Post 1, 2, or 3, which took place in a second Prep Room; see Table 3), the

315 respirators used had all been through between 10-12 prior aHP cycles. In all cases, the input

316 inoculum for each virus was set to the maximum available in each viral stock preparation.

317 For virus inactivation testing, respirator facepieces were inoculated with a controlled amount of 318 one or more surrogate virus species (refer to Table 2 for complete list). Each virus was added in 319 duplicate (or in quadruplicate during "Post 1-3" cycles of testing) droplets of $10 \mu \mathrm{L}$ each, on one 320 or more surfaces of each respirator type. Droplets were allowed to air-dry or absorb fully onto 
medRxiv preprint doi: https://doi.org/10.1101/2020.04.17.20068577; this version posted December 24, 2020. The copyright holder for this preprint (which was not certified by peer review) is the author/funder, who has granted medRxiv a license to display the preprint in perpetuity.

It is made available under a CC-BY-NC-ND 4.0 International license .

Derr et al, preprint for medRxiv, 2020

N95 aHP decontamination study

321 each respirator inside a Class II biosafety cabinet (BSC), before proceeding further. Selected

322 samples of each virus-inoculated respirator were left open to air, without aHP decontamination,

323 as a "drying-only" virus control. The remainder of each virus-inoculated facepiece was subjected

324 to aHP decontamination as described above (i.e. "decontaminated" samples). For each round of

325 viral testing, the duration of air-drying was matched to the duration of time needed for aHP

326 treatment of parallel respirators (i.e. including transport, respirator staging in the Prep Room,

327 aHP decontamination, aeration, and return to the viral testing location). After aHP treatment,

328 respirators, each virus-inoculated area was sliced out of the "dried" or "decontaminated"

329 respirators using dissection scissors. Each excised virus-spot encompassed all layers of the

330 respirator, to capture any virus that had absorbed beyond the surface fabric.

\section{Herpes simplex virus 1 and coxsackievirus B3 quantification}

332 Respirator areas inoculated with HSV-1 or CVB3 were transferred into individual Eppendorf 333 tubes and resuspended in a $250 \mu \mathrm{L}$ volume of cell media. Cell media consisted of Dulbecco's 334 Modified Eagle's Medium (DMEM) supplemented with 10\% fetal bovine serum (FBS) and 335 penicillin-streptomycin (Pen/Strep; $100 \mathrm{U} / \mathrm{mL}$; Thermo Fisher Scientific). The number of 336 infectious units, or plaque-forming units (PFU), for these viruses was determined by limiting 337 dilution onto confluent Vero detector cell monolayers (Cercopithecus aethiops monkey kidney 338 cells, ATCC ${ }^{\circledR}$ CCL-81 ${ }^{\mathrm{TM}}$ ). Plaque formation was assessed at 72 hours post infection (hpi), after

339 fixation and visualization of plaques using methylene blue staining (Figure 3). Duplicates of each

340 virus-inoculated respirator piece were frozen for titration at a subsequent date, separate from the

341 initial viral quantification. This allowed for experimental redundancy in terms of detector cell

342 monolayers, and reduced handling time for the large numbers of virus-respirator inoculation

343 sites.

\section{Bacteriophage phi6 quantification}

345 Respirator areas inoculated with phi6 bacteriophage were resuspended in $250 \mu \mathrm{L}$ of King's

346 medium B (KB). These were then quantified on lawns of Pseudomonas syringae pathovar

347 phaseolicola strain 1448A (Pph) using a previously described soft agar overlay protocol (40).

348 Briefly, $100 \mu 1$ logarithmic culture of Pph $\left(\mathrm{OD}_{600} \sim 0.5\right)$ and $100 \mu 1$ of the phage preparation

349 were sequentially added to $3 \mathrm{ml}$ of molten soft agar $(0.7 \%)$ maintained at $55^{\circ} \mathrm{C}$. The mixture was

350 quickly poured on top of a KB agar plate and dried in the biosafety cabinet before transferring to 
medRxiv preprint doi: https://doi.org/10.1101/2020.04.17.20068577; this version posted December 24, 2020. The copyright holder for this

preprint (which was not certified by peer review) is the author/funder, who has granted medRxiv a license to display the preprint in perpetuity.

It is made available under a CC-BY-NC-ND 4.0 International license .

Derr et al, preprint for medRxiv, 2020

N95 aHP decontamination study

351 a $28^{\circ} \mathrm{C}$ incubator. Alternatively, for enumeration of "inoculum" and "dried" samples, soft agar

352 Pph lawns were prepared and $10 \mu$ l dilutions of phage preparation were spotted (Figure 1).

353 Plaque forming units (PFU) were enumerated after $24-48$ hours of incubation at $28^{\circ} \mathrm{C}$.

\section{SARS-CoV-2 quantification}

355 All experiments with SARS-CoV-2 were conducted in the Pell Laboratory under biosafety level

3563 (BSL3) enhanced conditions using the USA-WA1/2020 isolate. SARS-CoV-2 was spotted onto

357 masks in quadruplicate and treated with aHP. After aHP treatment, Respirator areas inoculated

358 with SARS-CoV-2 were excised and resuspended in $250 \mu \mathrm{L}$ of DMEM supplemented with

359 sodium pyruvate, non-essential amino acids, antibiotics-antimycotics, and 2\% FBS. After

360 resuspension, viral titer was determined by tissue culture infectious dose 50 (TCID50) assay in

361 96-well plates, using Vero E6 cells. Briefly, $20 \mu \mathrm{L}$ of resuspended sample was added to 4 wells

362 containing $180 \mu \mathrm{L}$ of resuspension media. The added samples were then serially diluted 10-fold

363 down the plate, and the plates were incubated at $37^{\circ} \mathrm{C}$ for 96 -hours. At this time, cytopathic

364 effect (CPE) was scored, and titer was calculated using the method of Reed and Muench (41).

\section{Results}

\section{Chemical Verification and Biological Validation of Aerosolized $\mathrm{H}_{2} \mathrm{O}_{2}$ Process}

367 This study was intended to rigorously evaluate a protocol for decontamination and re-use of N95

368 respirators using aerosolized hydrogen peroxide (aHP) treatment. The study focused

369 predominantly on the $3 \mathrm{M} 8511$ respirator, while also extending this approach to other respirator

370 models (Table 1). The decontamination process was performed in the BSL3 enhanced facility,

371 enabling the assessment of inactivation of viruses spanning multiple biosafety levels, including

372 SARS-CoV-2 (Table 2). As described above (in Methods), the final aHP decontamination

373 process involved a "charge period" (initial aHP injection), followed by a "pulse period"

374 (intermittent aerosol injection for six intervals of 5-minutes each, after completion of the initial

375 charge period), and a final 20-minute "dwell period" or quiescent maintenance of the aHP room

376 conditions. Upon completion of the "dwell period", an aeration phase was initiated to evacuate

377 aHP from the room. Importantly, the aHP method used for decontamination was adapted from

378 that used to decontaminate solid equipment, to allow for the absorbent nature of N95 respirators.

379 The charge, pulse, and dwell period parameters were adjusted to optimize cycle times (Table 3) 
medRxiv preprint doi: https://doi.org/10.1101/2020.04.17.20068577; this version posted December 24, 2020. The copyright holder for this preprint (which was not certified by peer review) is the author/funder, who has granted medRxiv a license to display the preprint in perpetuity.

It is made available under a CC-BY-NC-ND 4.0 International license .

Derr et al, preprint for medRxiv, 2020

N95 aHP decontamination study

380 as well as to account for biological indicator and virology results. Our initial tests utilized a 40-

381 minute pulse period with no dwell time (Table 3: "Initial" parameters), which was reduced to 30

382 minutes in subsequent runs ("Modification 1") to optimize overall cycle time and reduce residual

$383 \mathrm{H}_{2} \mathrm{O}_{2}$ on respirator surfaces. Upon minor failures of biological indicators and viral inactivation

384 (see below and Table 4), we incorporated a 20-minute dwell period to enhance inactivation

385 without increasing $\mathrm{H}_{2} \mathrm{O}_{2}$ concentrations (Table 3: "Final" parameters).

386 All chemical indicators located throughout the decontamination area (Prep Room) during all aHP

387 cycles revealed exposure to hydrogen peroxide. For cycles in which charge, pulse, and dwell

388 periods were utilized, all biological indicators similarly indicated successful decontamination,

389 with the exception of aHP cycles 3 and 5 (Table 4). In cycle 3 the additional dwell period was

390 not yet implemented, and BIs indicated an unsuccessful decontamination cycle (1 positive; 5

391 negative). During transfer of spore coupons to media after treatment cycle 5, it was noted that

392 external contamination of one spore coupon may have occurred, potentially resulting in the

393 single positive indicator for this specific BI. Overall, chemical and biological indicator results

394 supported aHP treatment and decontamination of N95 respirators with the room and cycle

395 parameters utilized in this study.

\section{Real-Time Hydrogen Peroxide Monitoring}

397 Real-time $\mathrm{H}_{2} \mathrm{O}_{2}$ measurement concentrations during the decontamination process were obtained

398 with a portable, real-time ATI PortaSens II monitor (summarized in Table 5). Instantaneous

$399 \mathrm{H}_{2} \mathrm{O}_{2}$ concentrations in the treatment area (inside containment or IC) were measured at $\geq 120$

400 ppm during the charge and pulse periods. Hydrogen peroxide concentrations in the corridor

401 outside the sealed entryway (outside containment or OC) were low or undetected (0 ppm)

402 throughout the decontamination cycle; however, occasional concentrations were detected up to 3

$403 \mathrm{ppm}$. These detectable levels were consistently associated with broken seals in the tape around

404 the door, and when corrected, immediately reduced aHP levels to $0 \mathrm{ppm}$.

405 At the timed start of the aeration phase, tape seals at the door entry were removed, and the door

406 was opened and left slightly ajar. Hydrogen peroxide concentrations at the door were

407 subsequently monitored at breathing zone height $(\mathrm{BZH})$ or 5 feet above floor level, until

408 concentrations measured $\leq 2 \mathrm{ppm}$. At this time research personnel entered the Prep Room to

409 measure $\mathrm{H}_{2} \mathrm{O}_{2}$ concentrations at respirator surfaces. Hydrogen peroxide concentrations were 
medRxiv preprint doi: https://doi.org/10.1101/2020.04.17.20068577; this version posted December 24, 2020. The copyright holder for this

preprint (which was not certified by peer review) is the author/funder, who has granted medRxiv a license to display the preprint in perpetuity.

It is made available under a CC-BY-NC-ND 4.0 International license .

Derr et al, preprint for medRxiv, 2020

N95 aHP decontamination study

410 observed to decline rapidly during aeration within 20-30 minutes of door opening. Initial

411 respirator surface concentrations (at fabric) typically exceeded $2 \mathrm{ppm}$. Subsequent respirator

412 drying to achieve $<1$ ppm required further staging under aeration (exhaust ventilation)

413 exceeding two hours, or overnight. Once $\mathrm{H}_{2} \mathrm{O}_{2}$ respirator surface concentrations were measured

$414<1 \mathrm{ppm}$, they were either subjected to further rounds of aHP, or collected and containerized for

415 further fit-testing or virus inactivation analysis.

\section{Hydrogen Peroxide Diffusion Sampler (Monitor) Analysis}

417 Diffusion samplers, also known as hydrogen peroxide vapor monitors (HPMs) were utilized to

418 assess researcher exposure levels to $\mathrm{H}_{2} \mathrm{O}_{2}$, with reference to the OSHA permissible exposure

419 limit (PEL) and ACGIH Threshold Limit Value $\left(\mathrm{TLV}^{\circledR}\right)$ of 1 ppm, as an eight-hour time-

420 weighted average (TWA). HPMs were also collected to monitor $\mathrm{H}_{2} \mathrm{O}_{2}$ build-up within respirator

421 containers prior to fit-testing (for test subject safety), and to verify that $\mathrm{H}_{2} \mathrm{O}_{2}$ concentrations

422 remained low in areas occupied by researchers (outside containment) during the decontamination

423 process (summarized in Table 6). All personal breathing zone HPM sampler results were

424 reported below sample detection limits $(<0.08 \mathrm{ppm},<0.1 \mathrm{ppm})$ for researchers conducting all

425 aHP processing activities (up to 3 hours). All results for HPMs placed within sealed respirator

426 transport containers were reported below sample detection limits $(<0.03 \mathrm{ppm})$, indicating no

427 residual $\mathrm{H}_{2} \mathrm{O}_{2}$ present through transport and respirator fit-testing. All results for HPMs collected

428 as OC samples were reported below sample detection limits $(<0.08 \mathrm{ppm}$, cycle $1 \mathrm{~b})$ and $<0.2$

429 ppm (cycle 11).

430 Qualitative and Quantitative Fit-Testing After aHP Decontamination

431 Fit-testing using both QLFT and QNFT on all 3M model 8511 respirators was assessed after the

432 first, fifth, and tenth decontamination cycles for both the male and female subject (summarized

433 in Figure 1). All respirators passed these fit tests. No other failures occurred, therefore with $95 \%$

434 confidence, at least $95 \%$ of $3 \mathrm{M}$ model 8511 respirators maintain successful N95 fit seal after ten

435 aHP decontamination cycles based on these data. QNFT results associated with 3M model 8511

436 respirators passed the minimum passing fit factor of 100, and the maximum quantifiable fit

437 factor of $200(+)$ in 8 of 9 tests. The numerical range of passing fit factors $(100-200)$, and

438 available sample quantity, limit statistical analysis. The consistently successful QNFT results 
medRxiv preprint doi: https://doi.org/10.1101/2020.04.17.20068577; this version posted December 24, 2020. The copyright holder for this preprint (which was not certified by peer review) is the author/funder, who has granted medRxiv a license to display the preprint in perpetuity.

It is made available under a CC-BY-NC-ND 4.0 International license .

Derr et al, preprint for medRxiv, 2020

N95 aHP decontamination study

439 verified QLFT findings, and support retention of successful respirator fitting following repeated

440 cycles of aHP decontamination and physical respirator stress.

441 QLFT and QNFT were also conducted on a smaller number of additional respirator models (as

442 indicated in Table 1 and Figure 1). For these respirator models, a maximum of 11 facepieces

443 were included, with all subjected to QLFT and a subset used for QNFT at various intervals.

444 Respirator models 3M 1860, 3M 1870+, 3M 9211+, Kimberly Clark PFR95, and Sperian N1125

445 passed all QLFT and QNFT tests. One respirator facepiece (3M model 1870+) experienced a

446 broken rubber strap when subjected to physical stress (e.g., stretching) after eight cycles of aHP.

447 This respirator was treated as a censored observation since it had successfully passed QLFT after

448 the first and fifth decontamination cycles but could not be fit-tested to assess fit seal and

449 filtration performance after the tenth cycle. Since fit test results varied widely by subject during

450 early testing of Alpha ProTech respirators, this model was discontinued from further study.

451 Given that no respirator models included in this study were designed for reuse, any apparent

452 shortcoming should not be interpreted as a failure of respirator performance when respirators are

453 used as designed and intended by the manufacturer.

\section{Respirator Filtration Efficiency Testing}

455 N95 respirator filtration efficiency testing was conducted on stockpiled 3M 8511 aHP-treated 456 respirators using the NIOSH test protocol under full-load test conditions (Table 7). No visible 457 degradation was found on inspection (e.g. metal nose guard discoloration, unusual thinning or 458 wear). Filtration efficiencies were found to exceed $95 \%$ for all eight respirators subjected to ten 459 cycles of aHP decontamination. Therefore, for at least ten aHP cycles, there were no adverse 460 impacts or loss of N95 respirator efficiencies. Two additional unused, untreated 3M 8511 461 respirators were additionally tested and found with slightly reduced filtration efficiencies $462(94.4 \%, 94.6 \%)$. These findings are consistent with the respirator manufacturer's 5-year shelf life 463 limitation; however, the overall respirator performance is maintained.

\section{Application of Multiple Viral Species to N95 Respirator Facepieces}

465 Viral inactivation on respirator facepieces was anticipated to occur both by the process of drying 466 or desiccation, and by the process of aHP decontamination. Multiple virus species were included 467 to test the decontamination potential of aHP against viruses in general, as well as against SARS- 
medRxiv preprint doi: https://doi.org/10.1101/2020.04.17.20068577; this version posted December 24, 2020. The copyright holder for this

preprint (which was not certified by peer review) is the author/funder, who has granted medRxiv a license to display the preprint in perpetuity.

It is made available under a CC-BY-NC-ND 4.0 International license.

Derr et al, preprint for medRxiv, 2020

N95 aHP decontamination study

468 CoV-2. These included: Pseudomonas phi6 bacteriophage (phi6), herpes simplex virus 1 (HSV-

469 1) strain F, coxsackievirus B3 (CVB3), and SARS-CoV-2 isolate USA-WA1/2020 (see Table 2

470 for details). In order to preserve overall respirator consumption during the pandemic, respirators

471 used for virus inactivation testing were ones previously subjected to aHP treatment and fit-

472 testing (see Methods for details). Initial application of virus to each of the four (4) $3 \mathrm{M}$ respirator

473 facepiece types revealed clear differences in relative absorption vs. fluid repulsion. 3M respirator

474 models $1870+$ and $9211+$ share a common outer fabric which is listed by the manufacturer as

475 having the highest fluid resistance of any N95 respirator (42). In our testing, these two respirator

476 models displayed no apparent absorption of virus inoculum in our tests, and instead dried with a

477 "coffee ring effect" on the respirator surface. In contrast, all other respirator types (Table 1)

478 experienced a combination of liquid spreading, absorption, and evaporative drying of the virus

479 inoculum droplet. Viruses were inoculated onto different areas of each respirator facepiece

480 model, including the outer and inner fabric surfaces, the elastic strap, and where present, the

481 inner and outer surface of the plastic exhalation valves (see Supplementary Figure 6).

\section{Inactivation of Multiple Viral Species by Air-Drying on Respirators}

483 To mimic the potential inactivation of viruses that could occur during a multi-hour session of

484 respirator use, we tested the amount of virus remaining after air-drying of virus applied to N95

485 respirators. For each round of viral testing, the duration of air-drying was matched to the

486 duration of time needed for aHP treatment of parallel virus-inoculated respirator areas (see Table

4874 for summary; detailed further below). These "drying-only" samples confirmed a partial loss of

488 viral infectiousness, ranging from 10-100-fold for phi6 and HSV-1, and 100-fold or greater for

489 CVB3 and SARS-CoV-2 (Figures 2-5; see also Supplementary Figure 8 and Supplementary

490 Table 1). For phi6 bacteriophage, this included 29 "drying-only" inoculation sites spanning three

491 independent rounds of testing (Figure 2). For HSV-1 and CVB3, this included 55 "drying-only"

492 inoculation sites for each virus species, spanning four independent rounds of testing (Figure 3

493 and Figure 4, respectively). Viral inactivation by drying was not markedly different on inner vs.

494 outer surfaces of the respirator models (Figures 2-5; see also Supplementary Table 1), or in

495 limited testing of alternative inoculation sites, such as elastic straps or plastic exhalation valves

496 (Figure 3A-B and Figure 4A-B). 
medRxiv preprint doi: https://doi.org/10.1101/2020.04.17.20068577; this version posted December 24, 2020. The copyright holder for this

preprint (which was not certified by peer review) is the author/funder, who has granted medRxiv a license to display the preprint in perpetuity.

It is made available under a CC-BY-NC-ND 4.0 International license .

Derr et al, preprint for medRxiv, 2020

N95 aHP decontamination study

\section{Decontamination of Virus-Inoculated Respirators by Aerosolized $\mathrm{H}_{2} \mathrm{O}_{2}$ Treatment}

While natural inactivation of viruses by air drying is an ancillary benefit of extended respirator use, our main goal was to assess the effectiveness of active decontamination by aHP treatment. For this purpose, parallel virus inoculation sites to those used in the air-drying experiments above were subjected to aHP treatment, using both "Modification 1" and "Final" parameters (see Table 3 for details). Viral testing of decontamination was conducted during six independent aHP cycles (summarized in Table 4), using the maximum inoculum titer available for each viral stock preparation. For phi6 bacteriophage, this included 37 "aHP-treated" sites spanning three independent rounds of testing (Figure 2). For HSV-1 and CVB3, this included 65 and 63 "aHPtreated" sites respectively, spanning four independent rounds of testing (Figure 3 and Figure 4). Across a total of 213 respirator sites inoculated with one of four virus species tested (Table 2; see also Supplementary Table 1), only 5 sites had any remaining infectious virus. Even these rare instances of virus positivity still entailed a 4-6 $\log _{10}$ reduction in viral load from the initial inoculum $\left(10^{6}\right.$ reduction for phi6, Figure $2 \mathrm{~B} ; 10^{5}$ reduction for HSV-1, Figure $3 \mathrm{~A} ; 10^{4}$ reduction for CVB3; Figure 4A-B). Three of these rare positive virus plaques were detected in an aHP cycle using the "Modification 1" parameters (Figure 2A and 3A; Table 4; see also

513 Supplementary Figure 8), and these were a key motivation to add a dwell time in the "Final" aHP

514 cycle parameters (Table 3). There was no observable difference in the effectiveness of aHP 515 decontamination for inner vs. outer surfaces of respirators (Figures 2-5; see also Supplementary

516 Table 1), or in limited testing of alternative inoculation sites such as elastic straps (Figure 3A-B 517 and Figure 4A-B). The success of virus inactivation by aHP treatment mirrored the results of 518 biological indicators (BIs) consisting of bacterial spore coupons (Table 4).

\section{Inactivation of SARS-CoV-2 by aHP Treatment}

520 Experimental testing of SARS-CoV-2 by aHP necessitated that all work be completed at BSL3.

521 These studies were conducted with the 3M 8511, 1860, and 1870+ N95 respirators, spanning two 522 independent rounds of testing (Figure 5). As with the surrogate virus species, SARS-CoV-2 was 523 first inoculated onto respirator facepieces. The "drying only" controls were left open to air, while 524 the decontaminated samples were subjected to aHP-treatment. The respirators used for SARS525 CoV-2 testing had been subjected to 10 prior rounds of aHP before virus inoculation. For SARS526 CoV-2, viral testing included 48 "drying-only" inoculation sites and 48 "aHP-treated" sites, 527 spanning two independent rounds of testing (Figure 4). We observed a partial loss of viral 
medRxiv preprint doi: https://doi.org/10.1101/2020.04.17.20068577; this version posted December 24, 2020. The copyright holder for this

preprint (which was not certified by peer review) is the author/funder, who has granted medRxiv a license to display the preprint in perpetuity.

It is made available under a CC-BY-NC-ND 4.0 International license .

Derr et al, preprint for medRxiv, 2020

N95 aHP decontamination study

528 infectiousness for SARS-CoV-2 due to drying (e.g. $10^{6.125}$ TCID50/mL input vs $\sim 10^{2}$

529 TCID50/mL after drying; Figure 5). Importantly, no infectious SARS-CoV-2 remained on any

530 respirator model after aHP decontamination (Figure 5).

\section{Discussion}

532 Based on a series of ten respirator decontamination cycles and multiple rounds of viral

533 inactivation testing, 3M 8511 and other similar N95 respirator models tested were found to be

534 suitable for aHP decontamination and reuse. We found that respirators could successfully pass

535 qualitative respirator fit testing through multiple cycles of the aHP decontamination process, and

536 ultimately passed filtration efficiency tests indicating no loss in filtration efficiency. Most studies

537 thus far have focused either on verifying fit-testing after respirator decontamination $(6,27,30)$,

538 or the ability of decontamination approaches to inactivate one or more virus species on

539 respirators $(25,29,31)$, but not both. A minority of N95 respirator decontamination studies have

540 included both fit-testing and measures of viral inactivation $(26,28)$, although none have

541 employed the aerosolized $\mathrm{H}_{2} \mathrm{O}_{2}$ method utilized here. Our study is unique in including multiple

542 measures of respirator integrity via fit-testing, as well as filtration efficiency, and robust

543 verification of viral inactivation using multiple surrogates and SARS-CoV-2 itself. The breadth

544 of this approach will extend the usefulness of this study beyond the current pandemic.

\section{Respirator Resilience for Re-Use}

546 Aerosolized $\mathrm{H}_{2} \mathrm{O}_{2}$ decontamination of the $\mathrm{N} 95$ respirators used in this study did not indicate any

547 adverse impact on final respirator filtration efficiency. Hydrogen peroxide concentrations were

548 controlled within the study, supporting effective microbial and viral decontamination, with

549 proper containment of aHP and with no detectable researcher exposure. These findings support

550 and reflect those of parallel studies using other forms of hydrogen peroxide vapor, and/or other

551 decontamination methods for $\mathrm{N} 95$ respirators $(24,26-28,30)$. In order to assess the $\mathrm{H}_{2} \mathrm{O}_{2}$

552 concentration profile during aHP decontamination (inside containment), and for comparison with

553 levels for different $\mathrm{H}_{2} \mathrm{O}_{2}$ decontamination methods, further studies would require use of real-time

554 instruments with a higher detection range and data logging features.

555 We are not aware of any studies reaching the ten cycles of aHP decontamination, with successful

556 fit-testing and verification of viral inactivation. As noted by the CDC, laboratory study 
medRxiv preprint doi: https://doi.org/10.1101/2020.04.17.20068577; this version posted December 24, 2020. The copyright holder for this

preprint (which was not certified by peer review) is the author/funder, who has granted medRxiv a license to display the preprint in perpetuity.

It is made available under a CC-BY-NC-ND 4.0 International license.

Derr et al, preprint for medRxiv, 2020

N95 aHP decontamination study

557 conditions such as those used in this study do not fully reflect clinical use conditions, which can

558 impact respirator fit and performance (43). While each facepiece was physically stressed

559 between each decontamination cycle as a proxy for use, then re-used by the same subjects during

560 fit-testing, sustained clinical use includes other pertinent stressors which may influence fit and

561 performance (e.g. build-up of facial oils, cosmetics, exhaled moisture, perspiration, intermittent

562 user adjustments) $(27,28,43)$. Future studies are needed to explore these impacts during re-use,

563 in combination with the metrics used in this study.

564 During this study, one 3M 1870+ respirator suffered a broken rubber strap during re-use. The

565 breakage occurred after eight cycles of aHP, during inter-cycle strap stretching to simulate re-

566 use. The breakage occurred at a point on the strap that corresponded with a penned hash mark

567 (used to denote decontamination cycle; see Supplementary Figure 7). There were no other

568 instances of failure for this or any other respirator models. This observation has relevance to real-

569 world decontamination scenarios, in which elastic or rubber straps may be damaged with cycle

570 marking. Care should be exercised when marking respirators during re-use protocols, and a

571 visual inspection for incidental damage is prudent.

\section{Viral and Biological Indicator Inactivation}

573 To model real-world scenarios in which healthcare staff may have aerosolized virus absorbed on

574 to their respirator, we inoculated viruses onto different respirator surfaces to thoroughly test for

575 the ability of aHP to inactivate viruses. We further tested several different components and

576 regions of the respirator to discern whether any differences in respirator construction (e.g. outer

577 vs. inner surface fabric) would influence viral inactivation. This work was inspired by early

578 efforts to verify viral inactivation in the context of N95 respirator surfaces, such as that of

579 Kenney et al. (25) We found no evidence of viral survival during the aHP decontamination

580 process. Relative to other similar studies using different decontamination methods to test viral

581 inactivation on N95 respirators, these data shown an equal or better inactivation of viruses in the

582 present study $(25,26,28,29,31)$. During establishment of aHP cycle process parameters, we

583 observed a biological indicator test failure (positive result), and corresponding virology test

584 failure associated with cycle 3, in which no dwell period was used. Commercial bioindicator

585 tests have been relied upon for sterilization processes over several years $(2,34)$. These data

586 suggest that the use of commercial spore-based biological indicators during decontamination of 
medRxiv preprint doi: https://doi.org/10.1101/2020.04.17.20068577; this version posted December 24, 2020. The copyright holder for this

preprint (which was not certified by peer review) is the author/funder, who has granted medRxiv a license to display the preprint in perpetuity.

It is made available under a CC-BY-NC-ND 4.0 International license .

Derr et al, preprint for medRxiv, 2020

N95 aHP decontamination study

587 N95 respirators provides a useful predictor of success or failure for viral inactivation as well. In

588 this study, we tested up to ten cycles of aHP decontamination, which meets or exceeds current

589 FDA recommendations for N95 respirator re-use following vapor-phase $\mathrm{H}_{2} \mathrm{O}_{2}$ decontamination.

$590 \quad(25-30)$.

591 Like SARS-CoV-1, SARS-CoV-2 has a high level of environmental stability (44-48). In terms

592 of virion characteristics, SARS-CoV-2 has a lipid-enveloped virion of $\sim 120 \mathrm{~nm}$, with no

593 icosahedral capsid core. The lipid envelope encloses a single-stranded, linear, positive-sense

594 RNA genome (summarized in Table 2). We used multiple virus species to test the viral

595 inactivation capabilities of aHP decontamination. These viruses represented multiple

596 characteristics of human viral pathogens, with a range of virion and genome types and sizes, and

597 previously documented environmental stability (49-51). Virions of herpes simplex virus 1

598 (HSV-1) and Pseudomonas phi6 bacteriophage have a lipid envelope, with an underlying

599 icosahedral capsid core. In contrast, coxsackievirus B3 (CVB3) is a non-enveloped or naked

600 icosahedral capsid virus. Prior work has shown that naked-capsid viruses have a higher stability

601 than enveloped viruses, thus providing a useful test of aHP sterilization abilities (49-51). While

602 most viruses utilized in this study are mammalian viruses requiring analysis in mammalian cell

603 lines at biosafety level 2 (BSL2), phi6 can be assayed more flexibly, using rapid bacterial

604 cultures (24-hour turnaround) at biosafety level 1. Phi6 is a natural pathogen phage of

605 Pseudomonas syringae pathovar phaseolicola, which is itself a bacterial pathogen of green

606 beans. We found that all viral species examined in this study were effectively sterilized by aHP,

607 comparable to the decontamination observed with commercial spore-based biological indicators

608 of sterilization. Together, this combination of respirator fit testing and virus inactivation testing

609 indicate that aHP is a suitable decontamination process to enable reuse of N95 respirators during

610 the COVID-19 pandemic.

611 Virus inactivation data associated with respirator analyses are impacted by the effects of viral

612 drying on hydrophobic respirator surfaces (31). Overall effectiveness of viral inactivation can be

613 consistently demonstrated through aHP process; however, there is no way to fully separate the

614 effects of air drying from the impacts of aHP. Clinical exposure to SARS-CoV-2 or other viral

615 pathogens would likewise entail conditions that allow viral drying prior to decontamination

616 and/or respirator re-use (e.g. virus may dry onto a respirator in the course of a work-shift, or air-

617 dry during respirator bagging for decontamination or direct re-use). If anything, our "drying- 
medRxiv preprint doi: https://doi.org/10.1101/2020.04.17.20068577; this version posted December 24, 2020. The copyright holder for this preprint (which was not certified by peer review) is the author/funder, who has granted medRxiv a license to display the preprint in perpetuity.

It is made available under a CC-BY-NC-ND 4.0 International license .

Derr et al, preprint for medRxiv, 2020

N95 aHP decontamination study

618 only" time frame was shorter than would likely occur in a clinical setting. This suggests that

619 emergency-protocols that involve respirator re-use after multiple days of drying, even without

620 aHP or other similar decontamination methods, are likely providing substantial levels of viral

621 inactivation $(22,43)$.

\section{Acknowledgements}

623 We appreciate the contributions of colleagues and scientists who provided intellectual input

624 and/or materials for this work. These include Joyce Jose, Susan Hafenstein, Anthony Schmitt,

625 Gregory Broussard, Michael Brignati, and Tim Simpson. We thank Dr. Paul Turner and his lab

626 for providing phi6 bacteriophage. We appreciate the contributions and support of Jim Crandall

627 and the Penn State Environmental Health and Safety staff, as well Theresa Engle and other

628 Occupational Medicine staff, who provided support in study implementation, and fit-testing. We

629 also thank Irene Miller as part of the Pell Lab decontamination staff, researchers, clinical staff, as

630 well as Neerav Goyal, Justin Soulier, and the healthcare providers of the Penn State Health

631 Milton S. Hershey Medical Center and College of Medicine.

632 This work was supported by the Pennsylvania State University. SARS-CoV-2 research in Dr.

633 Troy Sutton's laboratory was initiated by a seed grant from The Huck Institutes of Life Sciences

634 at Pennsylvania State University, and Dr. Sutton's research is further supported by the USDA

635 National Institute of Food and Agriculture, Hatch project 4605. 
medRxiv preprint doi: https://doi.org/10.1101/2020.04.17.20068577; this version posted December 24, 2020. The copyright holder for this preprint (which was not certified by peer review) is the author/funder, who has granted medRxiv a license to display the preprint in perpetuity.

It is made available under a CC-BY-NC-ND 4.0 International license .

Derr et al, preprint for medRxiv, 2020

N95 aHP decontamination study

\section{Tables}

638 Table 1: N-95 respirator facepiece models included in this study

\begin{tabular}{|l|l|l|l|l|l|}
\hline Brand \& model & $\begin{array}{l}\text { \# in } \\
\text { study }\end{array}$ & Style & Type & $\begin{array}{l}\text { Exhalation } \\
\text { valve }\end{array}$ & Notes \\
\hline 3M 8511 & 77 & molded & Non-surgical & yes & \\
\hline 3M 1860 & 10 & molded & Surgical & no & \\
\hline 3M 1870+ & 11 & folded & Surgical & no & Highest fluid resistance* \\
\hline 3M 9211+ & 12 & folded & Non-surgical & yes & Same fabric as 1870+ \\
\hline $\begin{array}{l}\text { Honeywell Sperian } \\
\text { N11125 }\end{array}$ & 5 & molded & Non-surgical & yes & \\
\hline Alpha ProTech & 65 & folded & Surgical & No & \\
\hline
\end{tabular}

$639 *$ Highest level of fluid resistance according to ASTM F1862 at $160 \mathrm{~mm} \mathrm{Hg} \mathrm{(42).}$

Table 2. Characteristics of virus species used to test inactivation by aerosolized

$$
\mathrm{H} 2 \mathrm{O} 2 \text {, as compared to SARS-CoV-2 }
$$

\begin{tabular}{|l|l|l|l|l|l|}
\hline \multicolumn{1}{|c|}{$\begin{array}{c}\text { Virus species } \\
\text { (abbreviation) }\end{array}$} & Diameter & $\begin{array}{c}\text { Capsid / virion } \\
\text { shape }\end{array}$ & $\begin{array}{c}\text { Genome type, } \\
\sim \text { size* }\end{array}$ & \multicolumn{1}{|c|}{$\begin{array}{c}\text { Taxonomic } \\
\text { family }\end{array}$} & $\begin{array}{c}\text { Biosafety } \\
\text { Level } \\
\text { (BSL) }\end{array}$ \\
\hline $\begin{array}{l}\text { Severe acute } \\
\text { respiratory syndrome } \\
\text { coronavirus } 2 \\
\text { (SARS-CoV-2) }\end{array}$ & $120 \mathrm{~nm}$ & $\begin{array}{l}\text { Enveloped, no } \\
\text { icosahedral capsid }\end{array}$ & $\begin{array}{l}\text { linear (+) ssRNA } \\
\text { genome, } \sim 30 \mathrm{kbp}\end{array}$ & Coronaviridae & BSL3 \\
\hline $\begin{array}{l}\text { Herpes simplex virus } \\
\text { 1(HSV-1) }\end{array}$ & $200 \mathrm{~nm}$ & $\begin{array}{l}\text { Enveloped, } \\
\text { icosahedral }\end{array}$ & $\begin{array}{l}\text { linear dsDNA } \\
\text { genome, } \sim 152 \mathrm{kbp}\end{array}$ & Herpesviridae & BSL2 \\
\hline $\begin{array}{l}\text { Coxsackie virus B3 } \\
\text { (CVB3) }\end{array}$ & $30 \mathrm{~nm}$ & $\begin{array}{l}\text { Non-enveloped } \\
\text { (naked), icosahedral }\end{array}$ & $\begin{array}{l}\text { linear }(+) \text { ssRNA } \\
\text { genome, } \sim 7.4 \mathrm{kbp}\end{array}$ & Picornaviridae & BSL2 \\
\hline $\begin{array}{l}\text { Pseudomonas phi6 } \\
\text { bacteriophage (phi6) }\end{array}$ & $85 \mathrm{~nm}$ & $\begin{array}{l}\text { Enveloped, } \\
\text { icosahedral }\end{array}$ & $\begin{array}{l}\text { segmented, } \\
\text { dsRNA genome, } \\
\sim 13.3 \mathrm{kbp}\end{array}$ & Cystoviridae & BSL1 \\
\hline
\end{tabular}

$644 *$ ds, double-stranded; ss, single-stranded; ssRNA genomes are either $(+)$ positive sense or $(-)$ 645 negative sense.

646 
medRxiv preprint doi: https://doi.org/10.1101/2020.04.17.20068577; this version posted December 24, 2020. The copyright holder for this preprint (which was not certified by peer review) is the author/funder, who has granted medRxiv a license to display the preprint in perpetuity.

It is made available under a CC-BY-NC-ND 4.0 International license .

Derr et al, preprint for medRxiv, 2020

N95 aHP decontamination study

647 Table 3: Optimization of aHP treatment parameters

\begin{tabular}{|c|c|c|c|c|c|}
\hline $\begin{array}{c}\text { aHP } \\
\text { Cycle \# }\end{array}$ & $\begin{array}{c}\text { Room } \\
\text { Volume (ft }\end{array}$ & $\begin{array}{c}\text { Charge } \\
\text { Period }\end{array}$ & $\begin{array}{c}\text { Pulse } \\
\text { Period }\end{array}$ & $\begin{array}{c}\text { Dwell } \\
\text { Period }\end{array}$ & $\begin{array}{c}\text { aHP } \\
\text { Parameter Set }\end{array}$ \\
\hline $1 \mathrm{a}$ & 1700 & $16: 20$ & $40: 00$ & $0: 00$ & Initial \\
\hline $1 \mathrm{~b}$ & 1700 & $16: 20$ & $40: 00$ & $0: 00$ & Initial \\
\hline 2 & 1700 & $11: 43$ & $30: 00$ & $0: 00$ & Modification 1 \\
\hline 3 & 1700 & $11: 43$ & $30: 00$ & $0: 00$ & Modification 1 \\
\hline 4 & 1700 & $11: 43$ & $30: 00$ & $0: 00$ & Modification 1 \\
\hline 5 & 1700 & $11: 43$ & $30: 00$ & $20: 00$ & Final \\
\hline 6 & 1700 & $11: 43$ & $30: 00$ & $20: 00$ & Final \\
\hline 7 & 1700 & $11: 43$ & $30: 00$ & $20: 00$ & Final \\
\hline 8 & 1700 & $11: 43$ & $30: 00$ & $20: 00$ & Final \\
\hline 9 & 1700 & $11: 43$ & $30: 00$ & $20: 00$ & Final \\
\hline 10 & 1700 & $11: 43$ & $30: 00$ & $20: 00$ & Final \\
\hline 11 & 1700 & $11: 43$ & $30: 00$ & $20: 00$ & Final \\
\hline 12 & 1700 & $11: 43$ & $30: 00$ & $20: 00$ & Final \\
\hline Post 1 & 1840 & $12: 41$ & $30: 00$ & $20: 00$ & Final* \\
\hline Post 2 & 1840 & $12: 41$ & $30: 00$ & $20: 00$ & Final \\
\hline Post 3 & 1840 & $12: 41$ & $30: 00$ & $20: 00$ & Final* \\
\hline
\end{tabular}

$648 *$ These cycles were carried out in a larger preparation room, which necessitated adjustment to

649 the charge time to account for the larger room size

650

651 
medRxiv preprint doi: https://doi.org/10.1101/2020.04.17.20068577; this version posted December 24, 2020. The copyright holder for this preprint (which was not certified by peer review) is the author/funder, who has granted medRxiv a license to display the preprint in perpetuity.

It is made available under a CC-BY-NC-ND 4.0 International license .

Derr et al, preprint for medRxiv, 2020

N95 aHP decontamination study

652 Table 4: Spore-based Biological indicator (BI) and Virus Inactivation Results

\begin{tabular}{|c|c|c|c|c|c|c|}
\hline $\begin{array}{c}\text { aHP } \\
\text { Cycle } \\
\#\end{array}$ & $\begin{array}{c}\text { aHP- } \\
\text { treated } \\
\text { Spore- } \\
\text { based } \\
\text { BIs } \\
\end{array}$ & $\begin{array}{c}\text { Control } \\
\text { Spore- } \\
\text { based } \\
\text { BIs }\end{array}$ & $\begin{array}{l}\text { Spore-based } \\
\text { BI Results }\end{array}$ & $\begin{array}{c}\text { aHP } \\
\text { parameter set }\end{array}$ & $\begin{array}{l}\text { Viruses } \\
\text { Tested }\end{array}$ & $\begin{array}{c}\text { Virus } \\
\text { Inactivation } \\
\text { Results }\end{array}$ \\
\hline $1 \mathrm{a}$ & 12 & 1 & PASS & Initial & & \\
\hline $1 \mathrm{~b}$ & 12 & 1 & PASS & Initial & & \\
\hline 2 & -- & -- & -- & Modification 1 & & \\
\hline 3 & 6 & 1 & FAIL $(1+/ 5-)$ & Modification 1 & $\begin{array}{l}\text { phi6, HSV1, } \\
\text { CVB3 }\end{array}$ & $\begin{array}{c}3 \text { of } 64 \text { sites } \\
\text { positive }\end{array}$ \\
\hline 4 & 6 & 1 & PASS & Modification 1 & & \\
\hline 5 & 6 & 1 & FAIL $*(1+/ 5-)^{*}$ & Final & & \\
\hline 6 & 6 & 1 & PASS & Final & HSV1, CVB3 & $\begin{array}{l}1 \text { of } 26 \text { sites } \\
\text { positive }\end{array}$ \\
\hline 7 & 6 & 1 & PASS & Final & & \\
\hline 8 & 6 & 1 & PASS & Final & & \\
\hline 9 & 6 & 1 & PASS & Final & & \\
\hline 10 & 6 & 1 & PASS & Final & & \\
\hline 11 & 6 & 1 & PASS & Final & $\begin{array}{c}\text { phi6, HSV1, } \\
\text { CVB3 }\end{array}$ & $\begin{array}{l}1 \text { of } 9 \text { sites } \\
\text { positive }\end{array}$ \\
\hline 12 & 6 & 1 & PASS & Final & & \\
\hline Post 1 & -- & -- & -- & Final & $\begin{array}{l}\text { phi6, HSV1, } \\
\text { CVB3 }\end{array}$ & $\begin{array}{l}0 \text { of } 66 \text { sites } \\
\text { positive }\end{array}$ \\
\hline Post 2 & 12 & 1 & PASS & Final & SARS-CoV-2 & $\begin{array}{l}0 \text { of } 24 \text { sites } \\
\text { positive }\end{array}$ \\
\hline Post 3 & 12 & 1 & PASS & Final & SARS-CoV-2 & $\begin{array}{l}0 \text { of } 24 \text { sites } \\
\text { positive }\end{array}$ \\
\hline
\end{tabular}

$653 *$ *In cycle 5, it was noted upon transfer of one spore coupon to media, post-treatment

654 contamination may have occurred.

655 
medRxiv preprint doi: https://doi.org/10.1101/2020.04.17.20068577; this version posted December 24, 2020. The copyright holder for this preprint (which was not certified by peer review) is the author/funder, who has granted medRxiv a license to display the preprint in perpetuity.

It is made available under a CC-BY-NC-ND 4.0 International license .

Derr et al, preprint for medRxiv, 2020

N95 aHP decontamination study

656 Table 5: Portable real-time $\mathrm{H}_{2} \mathrm{O}_{2}$ measurements, using ATI PortaSens II

\begin{tabular}{|c|c|c|c|c|c|}
\hline $\begin{array}{c}\text { aHP } \\
\text { Cycle } \\
\text { ID }\end{array}$ & $\begin{array}{l}\text { Measurement } \\
\text { Location* }\end{array}$ & $\begin{array}{l}\text { Measurement } \\
\text { Condition }\end{array}$ & $\begin{array}{c}\mathrm{H}_{2} \mathrm{O}_{2} \\
\text { Concentration } \\
\text { or range } \\
(\mathrm{ppm}) * *\end{array}$ & $\begin{array}{l}\text { Time period } \\
\text { to decayed } \\
\text { concentration } \\
\text { (minutes) }\end{array}$ & $\begin{array}{c}\text { aHP } \\
\text { Parameter set }\end{array}$ \\
\hline $1 \mathrm{a}$ & IC, wall port & Charge & $>120$ & -- & Initial \\
\hline $1 \mathrm{a}$ & $\mathrm{IC}$, wall port & Aeration, to entry & $2.5-57$ & 52 & Initial \\
\hline $1 b$ & IC, wall port & Charge & $>120$ & -- & Initial \\
\hline 2 & No data & No data & No data & No data & Modification 1 \\
\hline 3 & $\mathrm{IC}$, door open & Aeration, to entry & $1.5-11.6$ & 20 & Modification 1 \\
\hline 3 & IC, door open & $\begin{array}{l}\text { Aeration, to respirator } \\
\text { measurement }\end{array}$ & $1.5-0.8$ & 40 & Modification 1 \\
\hline 4 & IC, door open & Aeration, to entry & $2-10.6$ & 20 & Modification 1 \\
\hline 4 & respirator surface & After overnight drying & $0-3$ & overnight & Modification 1 \\
\hline 5 & IC, wall port & Charge & $>120$ & -- & Final \\
\hline 6 & $\mathrm{IC}$, wall port & Pulse & 120 & -- & Final \\
\hline 6 & respirator surface & After overnight drying & 0 & overnight & Final \\
\hline 7 & $\mathrm{IC}$, wall port & Charge & $>120$ & -- & Final \\
\hline 7 & OC, seal check(s) & Charge, Pulse, Dwell & 0 & -- & Final \\
\hline 7 & $\mathrm{IC}$, door open & Aeration, to entry & $2-7$ & 27 & Final \\
\hline 7 & respirator surface & After overnight drying & 0 & overnight & Final \\
\hline 8 & IC, wall port & Pulse & 88 & -- & Final \\
\hline 9 & IC, wall port & Charge & $>120$ & -- & Final \\
\hline 9 & IC, door open & Aeration, to entry & $1.6-24$ & 20 & Final \\
\hline 9 & respirator surface & $\begin{array}{l}\text { Aeration, to respirator } \\
\text { measurement }\end{array}$ & $<1$ & 85 & Final \\
\hline 10 & OC, seal check & Pulse, door seal repair & $0-1.6$ & -- & Final \\
\hline 10 & IC, door open & Aeration, to entry & $1.3-15$ & 32 & Final \\
\hline 10 & respirator surface & After overnight drying & $<1$ & overnight & Final \\
\hline 11 & IC, door open & Aeration, to entry & $1-13.6$ & 35 & Final \\
\hline 11 & respirator surface & After overnight drying & $<1$ & overnight & Final \\
\hline Post & respirator surface & $\begin{array}{l}\text { Aeration to } 1 \mathrm{ppm}, \\
\text { respirator data log }\end{array}$ & $1-8.1$ & 150 & Final \\
\hline
\end{tabular}

* Measurement Location: IC - inside containment, (wall port) - through sealable wall port, (door open) door ajar after door seal removed, OC - outside containment, (seal check) - Prep Room door tape seal, (respirator surface) - at respirator surface following room entry.

661 represents starting concentration (prior to decay). 
medRxiv preprint doi: https://doi.org/10.1101/2020.04.17.20068577; this version posted December 24, 2020. The copyright holder for this preprint (which was not certified by peer review) is the author/funder, who has granted medRxiv a license to display the preprint in perpetuity.

It is made available under a CC-BY-NC-ND 4.0 International license .

Derr et al, preprint for medRxiv, 2020

N95 aHP decontamination study

663 Table 6: Hydrogen peroxide diffusion sampler (HPM) data

\begin{tabular}{|c|l|l|c|c|}
\hline $\begin{array}{c}\text { aHP } \\
\text { Cycle } \\
\text { ID }\end{array}$ & \multicolumn{1}{|c|}{ Sample Type } & \multicolumn{1}{|c|}{ Location Notes* } & $\begin{array}{c}\mathbf{H}_{2} \mathbf{O}_{2} \\
(\mathbf{p p m})^{* * *}\end{array}$ & $\begin{array}{c}\text { Sampling } \\
\text { Period } \\
\text { (minutes) }\end{array}$ \\
\hline 1a & $\begin{array}{l}\text { Researcher A - } \\
\text { personal breathing zone }\end{array}$ & $\begin{array}{l}\text { Sampler at worker lapel; transit in all } \\
\text { service areas }\end{array}$ & $<0.1$ & 143 \\
\hline $1 \mathrm{~b}$ & $\begin{array}{l}\text { Researcher B - } \\
\text { personal breathing zone }\end{array}$ & $\begin{array}{l}\text { Sampler at worker lapel; transit in all } \\
\text { service areas }\end{array}$ & $<0.08$ & 185 \\
\hline $1 \mathrm{~b}$ & area sample & Door Seal (OC), breathing zone height & $<0.08$ & 183 \\
\hline $1 \mathrm{~b}$ & respirator container & 3M 1860 (within brown paper bag) & $<0.03$ & 461 \\
\hline $1 \mathrm{~b}$ & respirator container & 3M 9211+ (bag) & $<0.03$ & 518 \\
\hline $1 \mathrm{~b}$ & respirator container & $\begin{array}{l}\text { Alpha Protech PFL (within brown } \\
\text { paper bag) }\end{array}$ & $<0.03$ & 497 \\
\hline $1 \mathrm{~b}$ & respirator container & $\begin{array}{l}\text { Alpha Protech PFL (within brown } \\
\text { paper bag) }\end{array}$ & $<0.03$ & 510 \\
\hline 11 & area sample & Door Seal (OC), breathing zone height & $<0.2$ & 110 \\
\hline
\end{tabular}

$664 * \mathrm{C}$ (charge period), $\mathrm{P}$ (pulse period), D (dwell period), A (aeration phase)

$665 * *$ “ $<$ Value" indicates sample analysis was below limit of quantitation (LOQ) based on sampler 666 diffusion rate and air volume collected. Time-weighted average (TWA) not calculated for results 667 reported $<$ LOQ. The OSHA PEL and ACGIH TLV ${ }^{\circledR}$ exposure standard for hydrogen peroxide is 668 1ppm eight-hour TWA.

$669 * * *$ Sampling period varied by sampling objectives.

670

671 
medRxiv preprint doi: https://doi.org/10.1101/2020.04.17.20068577; this version posted December 24, 2020. The copyright holder for this preprint (which was not certified by peer review) is the author/funder, who has granted medRxiv a license to display the preprint in perpetuity.

It is made available under a CC-BY-NC-ND 4.0 International license .

Derr et al, preprint for medRxiv, 2020

N95 aHP decontamination study

\section{Table 7: Respirator filtration efficiency testing results following 10 cycles of}

673 aerosolized hydrogen peroxide decontamination

\begin{tabular}{|c|c|c|c|c|c|c|}
\hline \multicolumn{7}{|c|}{ Full-loading efficiencies - 3M Model 8511 (N95 respirator)* } \\
\hline $\begin{array}{c}\text { Sample } \\
\text { ID** }\end{array}$ & $\begin{array}{c}\text { Initial } \\
\text { Test Flow } \\
\text { Rate } \\
(\text { LPM })\end{array}$ & $\begin{array}{c}\text { Initial Test } \\
\text { Resistance } \\
\left(\mathrm{mmH}_{2} \mathrm{O}\right)\end{array}$ & $\begin{array}{c}\text { Initial Test } \\
\text { Penetration } \\
(\%)\end{array}$ & $\begin{array}{c}\text { Maximum } \\
\text { Penetration } \\
(\%)\end{array}$ & $\begin{array}{c}\text { Filter } \\
\text { Efficiency*** } \\
(\%)\end{array}$ & Result \\
\hline $\mathrm{MS}-1$ & 84 & 6.5 & 0.67 & 2.29 & 97.71 & Pass \\
\hline $\mathrm{MS}-2$ & 85 & 6.7 & 0.82 & 2.38 & 97.62 & Pass \\
\hline $\mathrm{MS}-3$ & 84 & 6.9 & 1.46 & 4.16 & 95.84 & Pass \\
\hline $\mathrm{MS}-4$ & 85 & 6.8 & 1.75 & 4.14 & 95.86 & Pass \\
\hline FS - 1 & 85 & 7.1 & 2.02 & 4.58 & 95.42 & Pass \\
\hline FS - 2 & 84 & 6.6 & 1.47 & 3.5 & 96.50 & Pass \\
\hline FS - 3 & 85 & 6.6 & 0.20 & 2.37 & 97.63 & Pass \\
\hline FS - 4 & 86 & 7.0 & 1.47 & 4.12 & 95.88 & Pass \\
\hline $\begin{array}{c}\text { Test } \\
\text { specification }\end{array}$ & $81-89$ & & & $\leq 5.0$ & $\geq 95.0$ & \\
\hline
\end{tabular}

* Respirator testing analysis performed by ICS Laboratories of Brunswick, $\mathrm{OH}$

$675 * *$ MS, FS $-[\mathrm{x}]$ Male subject or female subject sample respirator id

$676 * * *$ Filter efficiency percent is based on maximum penetration value. 
medRxiv preprint doi: https://doi.org/10.1101/2020.04.17.20068577; this version posted December 24, 2020. The copyright holder for this preprint (which was not certified by peer review) is the author/funder, who has granted medRxiv a license to display the preprint in perpetuity.

It is made available under a CC-BY-NC-ND 4.0 International license .

Derr et al, preprint for medRxiv, 2020

N95 aHP decontamination study

\section{Figures}

678

679

Figure 1: Sequential fit testing (QLFT \& QNFT) of N95 respirators subjected to

680 repeated aHP decontamination cycles.

681

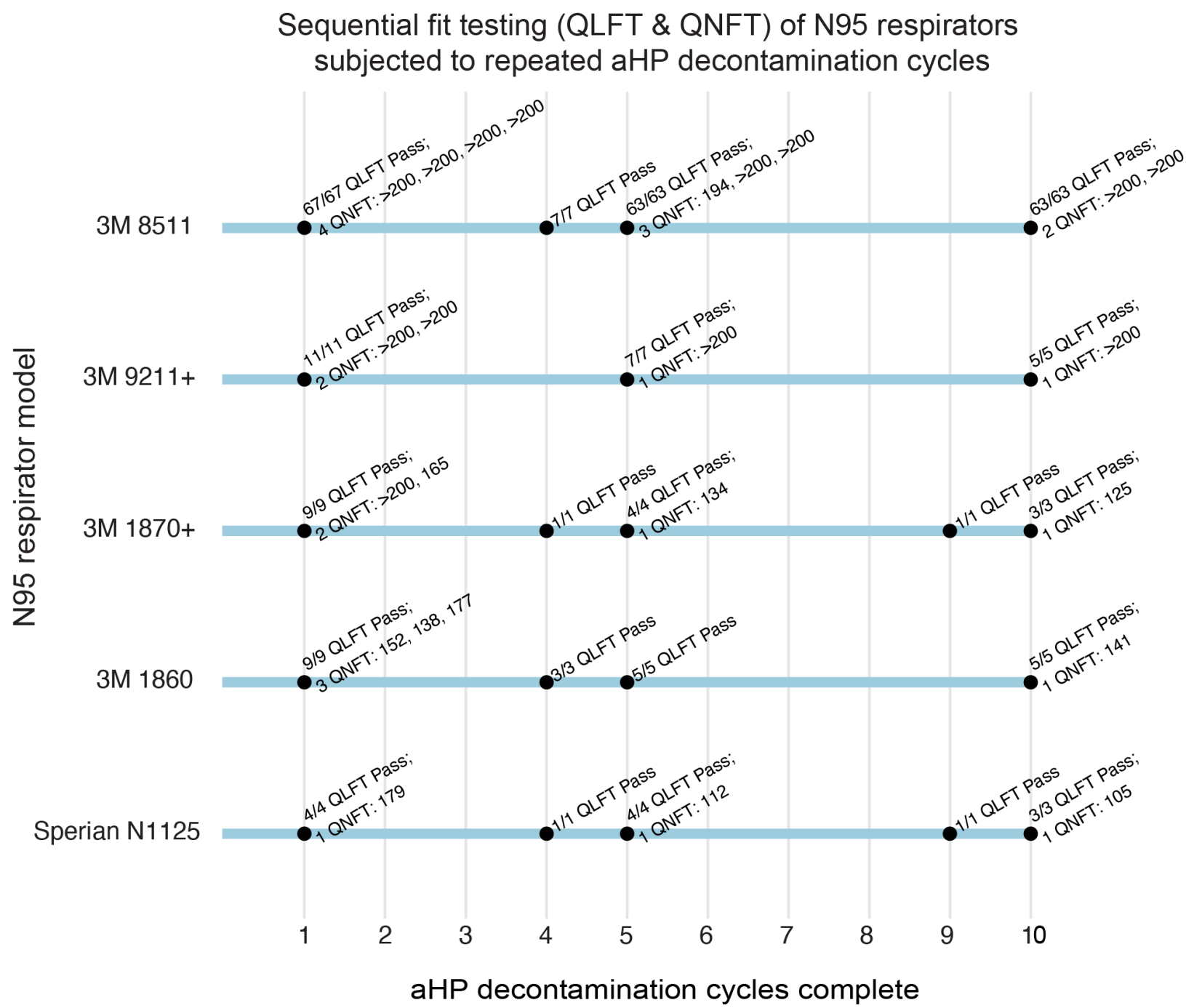

683 Figure 1: Sequential fit testing (QLFT \& QNFT) of N95 respirators subjected to repeated

684 aHP decontamination cycles. Results demonstrate that all 3M model 8511 respirators

685 successfully pass QLFT and QNFT after 1, 5, and 10 cycles. In particular, 8 of 9 QNFT results

686 for the 3M model 8511 respirator surpassed a fit factor of 200, the maximum reportable by the

687 test method - providing qualitative, yet objective, evidence of the safety margin related to fit 
medRxiv preprint doi: https://doi.org/10.1101/2020.04.17.20068577; this version posted December 24, 2020. The copyright holder for this preprint (which was not certified by peer review) is the author/funder, who has granted medRxiv a license to display the preprint in perpetuity.

It is made available under a CC-BY-NC-ND 4.0 International license .

Derr et al, preprint for medRxiv, 2020

N95 aHP decontamination study

688 integrity after 10 aHP decontamination cycles. All respirator models except Alpha Protech

689 (which had inconsistent fit-test results; see Methods for details) passed all QLFT and QNFT to

690 which they were subjected. Models Alpha ProTech (aHP cycle 1) and Kimberly Clark (aHP

691 cycle 2) were only included for a single cycle and are thus not shown here.

692 
medRxiv preprint doi: https://doi.org/10.1101/2020.04.17.20068577; this version posted December 24, 2020. The copyright holder for this preprint (which was not certified by peer review) is the author/funder, who has granted medRxiv a license to display the preprint in perpetuity.

It is made available under a CC-BY-NC-ND 4.0 International license .

Derr et al, preprint for medRxiv, 2020

N95 aHP decontamination study

693 Figure 2: Infectious titer of phi6 bacteriophage inoculated on N95 respirator

694 facepieces was eliminated after aerosolized $\mathrm{H}_{2} \mathbf{O}_{2}$ decontamination.

695

\section{phi6 titer after drying or aHP treatment}

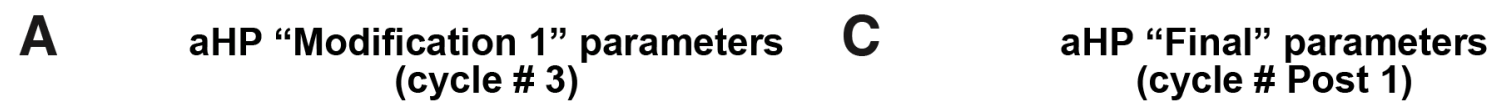

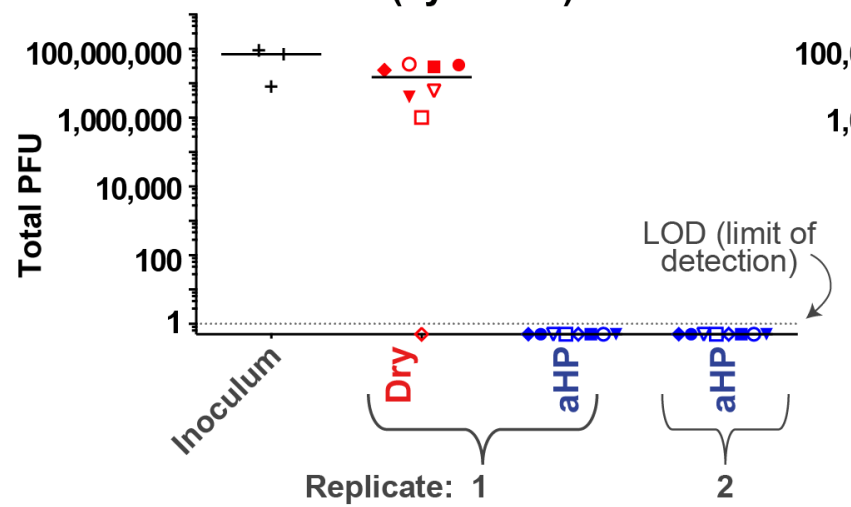

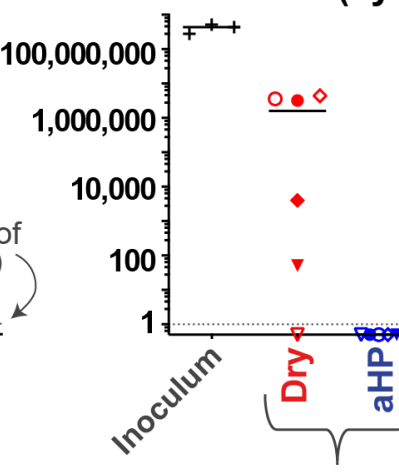

Replicate: 1
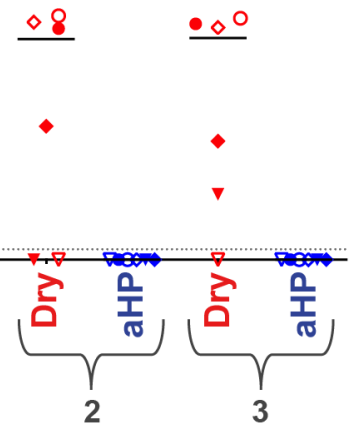

Undiluted

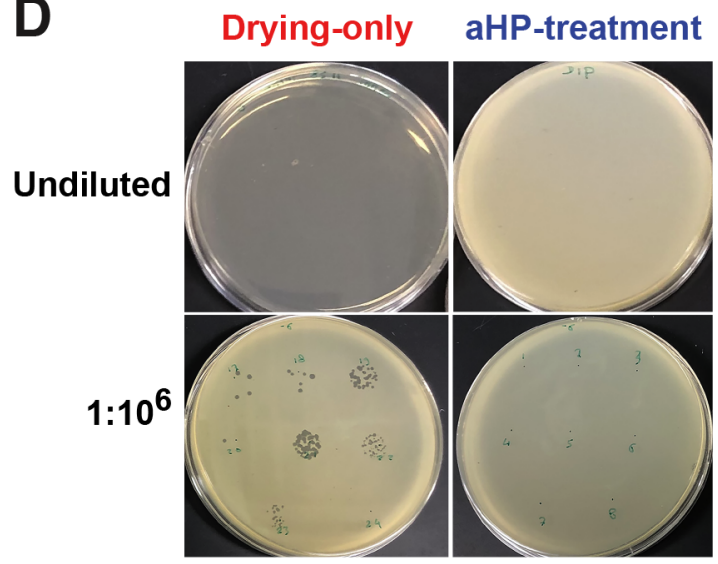

B

aHP "Final" parameters

(cycle \# 11)

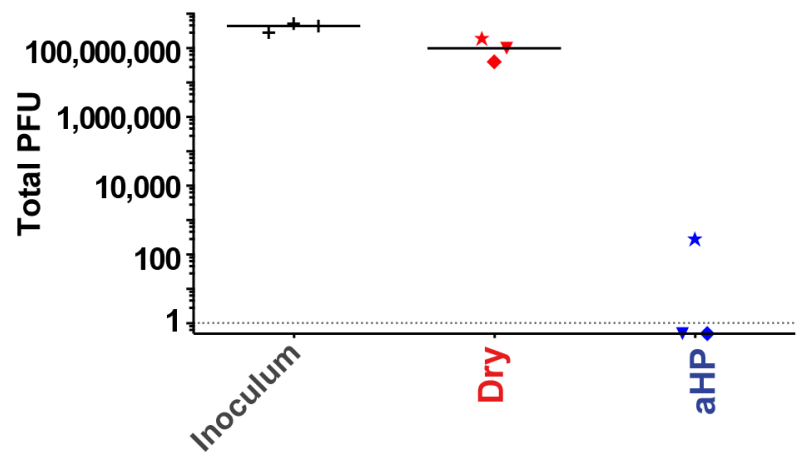

Inoculated surface Outer surface (filled) Inner surface (clear) $\nabla \square \circ \diamond$

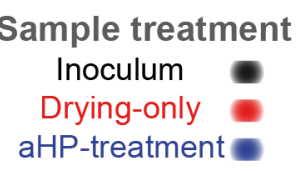

Figure 2: Infectious titer of phi6 bacteriophage inoculated on N95 respirator facepieces was eliminated after aerosolized $\mathrm{H}_{2} \mathrm{O}_{2}$ (aHP) decontamination. (A-C) Data are plotted separately for each aHP cycle in which viral testing was done (see Table 4). Multiple models of N95 respirator (see Table 1) were inoculated and either treated as "drying only" controls (red), or subjected to aHP treatment (blue). The respirator surface and model are indicated by the symbol 
medRxiv preprint doi: https://doi.org/10.1101/2020.04.17.20068577; this version posted December 24, 2020. The copyright holder for this preprint (which was not certified by peer review) is the author/funder, who has granted medRxiv a license to display the preprint in perpetuity.

It is made available under a CC-BY-NC-ND 4.0 International license .

Derr et al, preprint for medRxiv, 2020

N95 aHP decontamination study

702 shape and fill. The median of all points within a given aHP cycle and treatment is indicated by a

703 solid horizontal line. The dashed horizontal line indicates the limit of detection (LOD) at 1 viral

704 plaque-forming unit (PFU), in the resuspended but undiluted volume from the site of viral

705 inoculation. (D) Image depicts Petri dish plating of bacterial lawns exposed to phi6 from drying-

706 only (left side) or aHP-treated (right side) respirator inoculation sites. These were applied to the

707 bacterial lawn either as an undiluted resuspension (top row) or 1:106 dilution applied to focal

708 points (bottom row). For phi6, the only positive plaque occurring after aHP treatment occurred

709 on in a round of testing without replicate samples (aHP cycle 11), and thus could not be

710 validated. For the purposes of illustrating the decontaminated sites where zero plaques were

711 detected, these numbers were replaced with fractional values $(0.5)$, to allow their visualization on

712 this log-scale plot. See Supplementary Table 1 for all data values. 
medRxiv preprint doi: https://doi.org/10.1101/2020.04.17.20068577; this version posted December 24, 2020. The copyright holder for this preprint (which was not certified by peer review) is the author/funder, who has granted medRxiv a license to display the preprint in perpetuity.

It is made available under a CC-BY-NC-ND 4.0 International license .

Derr et al, preprint for medRxiv, 2020

N95 aHP decontamination study

714 Figure 3: Infectious titer of HSV-1 inoculated on N95 respirator facepieces was

715 reduced by drying and eliminated after aerosolized $\mathrm{H}_{2} \mathrm{O}_{2}$ decontamination.

716

HSV-1 titer after drying or aHP treatment

A aHP "Modification 1" parameters B aHP "Final" parameters

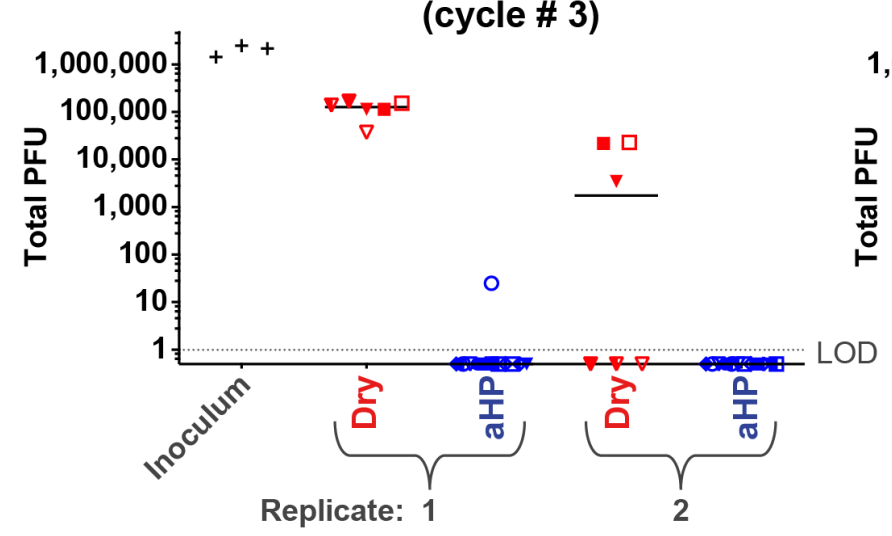

Sample treatment Inoculum Drying-only aHP-treatment

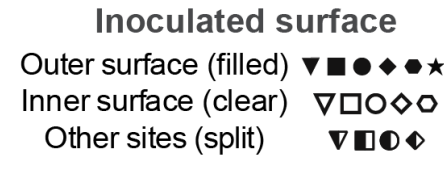

Inoculated surface Other sites (split)

$\nabla 000$

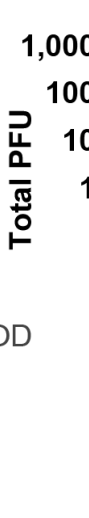

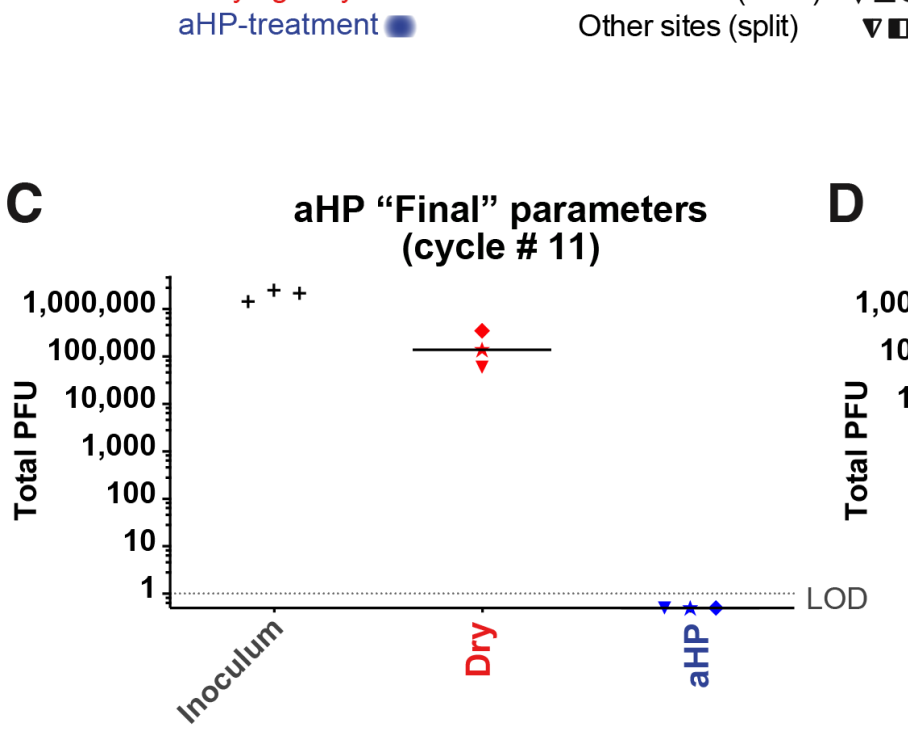

717

718

719

720

721

722
D

Figure 3: Infectious titer of HSV-1 inoculated on $\mathrm{N95}$ respirator facepieces was reduced by drying and eliminated after aerosolized $\mathrm{H}_{2} \mathrm{O}_{2}$ (aHP) decontamination. (A-D) Data are plotted separately for each aHP cycle in which viral testing was done (see Table 4). For HSV-1,

21 the sole positive plaque after aHP treatment occurred in aHP cycle \#3, when the "Modification 22 1" parameters were in use (Tables 3-4). This failure, in concert with a spore-based biological 
medRxiv preprint doi: https://doi.org/10.1101/2020.04.17.20068577; this version posted December 24, 2020. The copyright holder for this preprint (which was not certified by peer review) is the author/funder, who has granted medRxiv a license to display the preprint in perpetuity.

It is made available under a CC-BY-NC-ND 4.0 International license .

Derr et al, preprint for medRxiv, 2020

N95 aHP decontamination study

723 indicator and 2 CVB3 plaques (Figure 4) motivated the addition of a "dwell time" in the final

724 aHP parameter. As in Figure 2, multiple models of N95 respirator (see Table 1) were inoculated

725 and either treated as "drying only" controls (red), or subjected to aHP treatment (blue). The

726 respirator surface and model are indicated by the symbol shape and fill. The median of all points

727 within a given aHP cycle and treatment is indicated by a solid horizontal line. The dashed

728 horizontal line indicates the limit of detection (LOD) at 1 viral plaque-forming unit (PFU), in the

729 resuspended but undiluted volume from the site of viral inoculation. For the purposes of

730 illustrating the decontaminated sites where zero plaques were detected, these numbers were

731 replaced with fractional values (0.5), to allow their visualization on this log-scale plot. Note that

732 the same HSV-1 starting inoculum values (titered in triplicate) are included on each plot, for

733 comparison to drying and aHP-treated values. See Supplementary Table 1 for all data values. 
medRxiv preprint doi: https://doi.org/10.1101/2020.04.17.20068577; this version posted December 24, 2020. The copyright holder for this preprint (which was not certified by peer review) is the author/funder, who has granted medRxiv a license to display the preprint in perpetuity.

It is made available under a CC-BY-NC-ND 4.0 International license .

Derr et al, preprint for medRxiv, 2020

N95 aHP decontamination study

Figure 4: Infectious titer of CVB3 inoculated on N95 respirator facepieces was

\section{CVB3 titer after drying or aHP treatment}

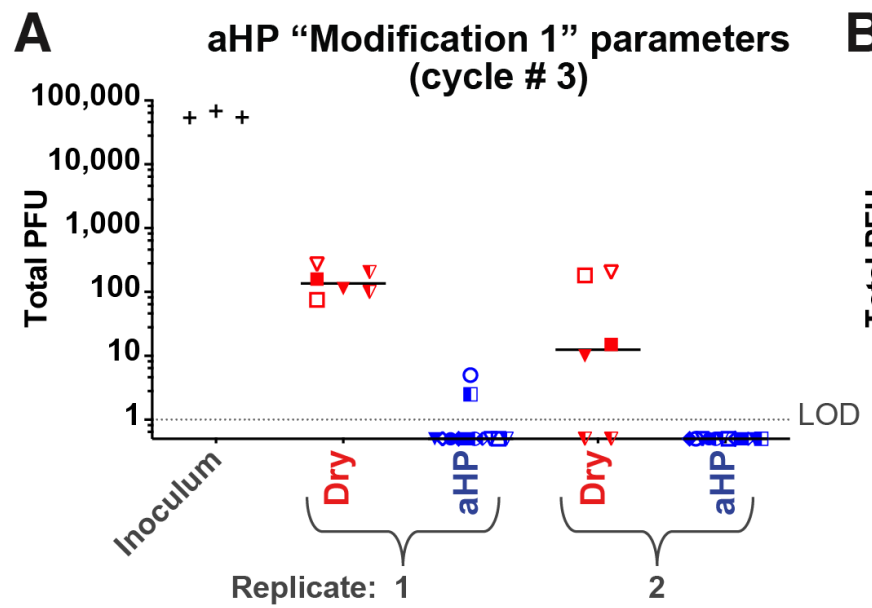

Sample treatment Inoculum Drying-only aHP-treatment
Inoculated surface Outer surface (filled) Inner surface (clear) Other sites (split)

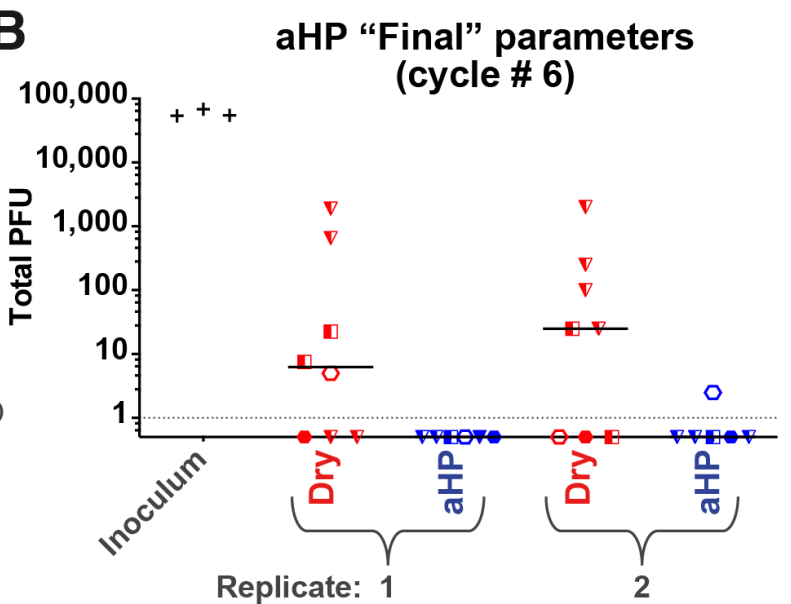

Replicate: 1 $\nabla \square 0 \diamond 0$

$\nabla 00 \bullet$
Respirator model
$\nabla \quad 8511$
1870+
○ 9211+
$\diamond 1860$
- Protech
$\star$ Sperian
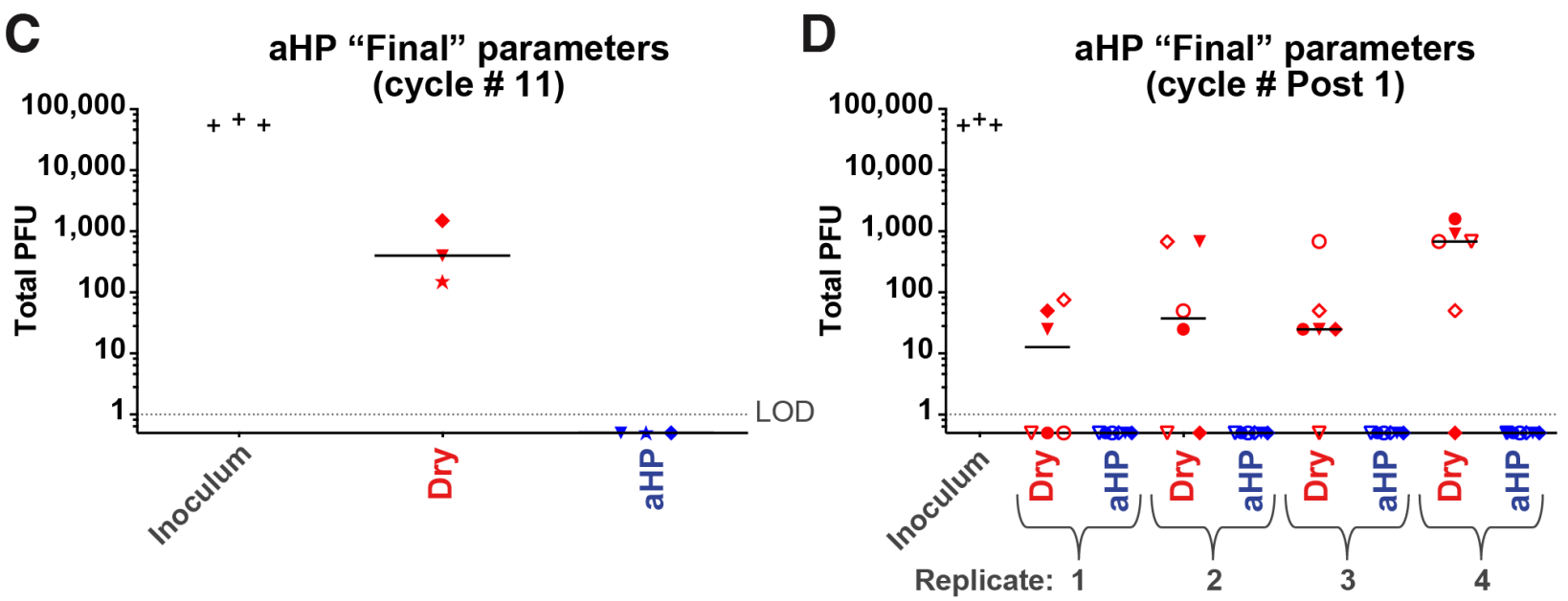

Figure 4: Infectious titer of CVB3 inoculated on N95 respirator facepieces was reduced by drying and eliminated after aerosolized $\mathrm{H}_{2} \mathrm{O}_{2}(\mathrm{aHP})$ decontamination. (A-D) Data are plotted separately for each aHP cycle in which viral testing was done (see Table 4). For CVB3, two positive plaques after aHP treatment occurred in aHP cycle \#3, when the "Modification 1" 
medRxiv preprint doi: https://doi.org/10.1101/2020.04.17.20068577; this version posted December 24, 2020. The copyright holder for this preprint (which was not certified by peer review) is the author/funder, who has granted medRxiv a license to display the preprint in perpetuity.

It is made available under a CC-BY-NC-ND 4.0 International license .

Derr et al, preprint for medRxiv, 2020

N95 aHP decontamination study

743 parameters were in use (Tables 3-4). This failure, in concert with a spore-based biological

744 indicator and $1 \mathrm{HSV}-1$ plaques (Figure 4) motivated the addition of a "dwell time" in the final

745 aHP parameter. The only other positive CVB3 plaque after aHP treatment occurred in aHP cycle

7466 (B), and no plaques were detected in the replicate or in parallel samples. As in Figure 2,

747 multiple models of N95 respirator (see Table 1) were inoculated and either treated as "drying

748 only" controls (red), or subjected to aHP treatment (blue). The respirator surface and model are

749 indicated by the symbol shape and fill. The median of all points within a given aHP cycle and

750 treatment is indicated by a solid horizontal line. The dashed horizontal line indicates the limit of

751 detection (LOD) at 1 viral plaque-forming unit (PFU), in the resuspended but undiluted volume

752 from the site of viral inoculation. For the purposes of illustrating the decontaminated sites where

753 zero plaques were detected, these numbers were replaced with fractional values (0.5), to allow

754 their visualization on this log-scale plot. Note that the same CVB3 starting inoculum values

755 (titered in triplicate) are included on each plot, for comparison to drying and aHP-treated values.

756 See Supplementary Table 1 for all data values. 
medRxiv preprint doi: https://doi.org/10.1101/2020.04.17.20068577; this version posted December 24, 2020. The copyright holder for this preprint (which was not certified by peer review) is the author/funder, who has granted medRxiv a license to display the preprint in perpetuity.

It is made available under a CC-BY-NC-ND 4.0 International license .

Derr et al, preprint for medRxiv, 2020

N95 aHP decontamination study

758

759

760

Figure 5: Infectious titer of SARS-CoV-2 inoculated on N95 respirator facepieces was reduced by drying and eliminated after aerosolized $\mathrm{H}_{2} \mathrm{O}_{2}$ decontamination.

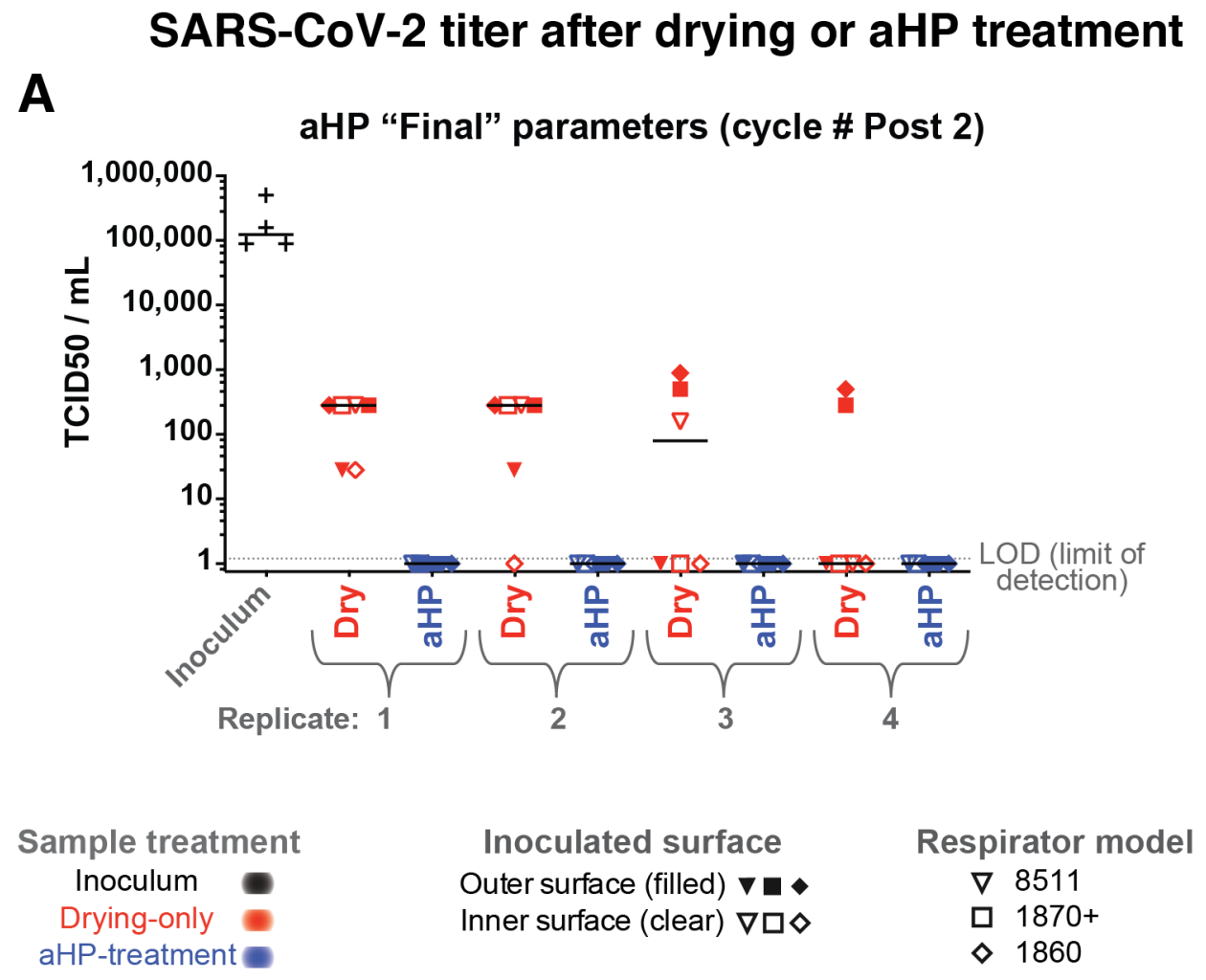

B

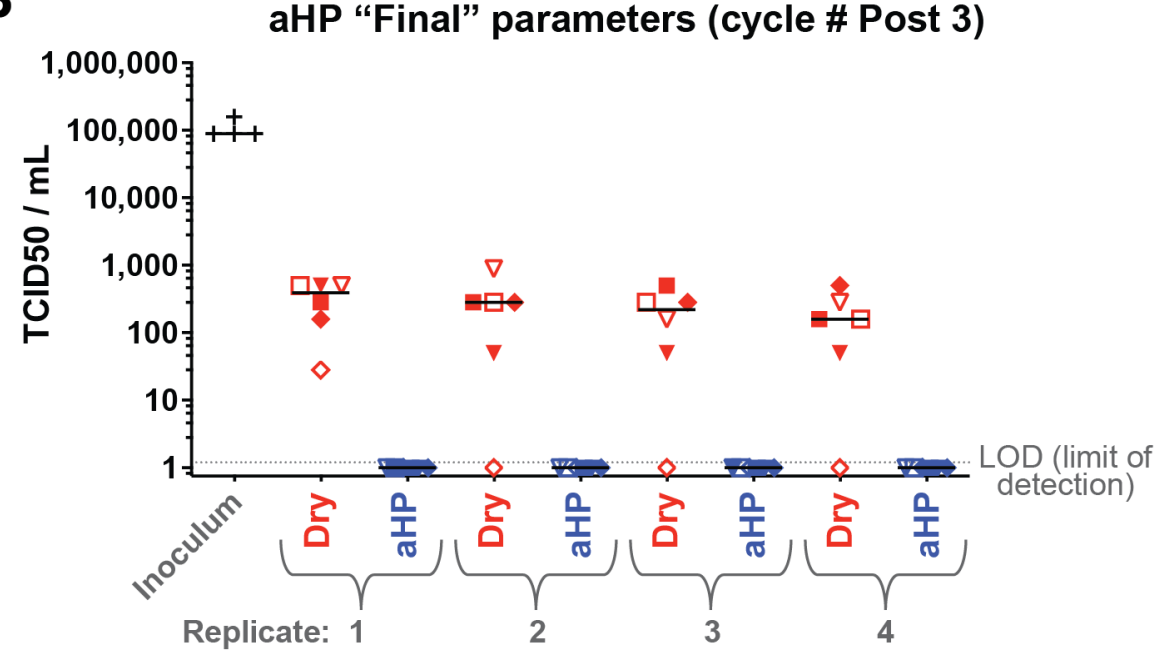

762 Figure 4: Infectious titer of SARS-CoV-2 inoculated on N95 respirator facepieces was

763 reduced by drying and eliminated after aerosolized $\mathrm{H}_{2} \mathrm{O}_{2}$ (aHP) decontamination. (A-B)

764 Data are plotted separately for each aHP cycle in which viral testing was done (see Table 4). For 
medRxiv preprint doi: https://doi.org/10.1101/2020.04.17.20068577; this version posted December 24, 2020. The copyright holder for this preprint (which was not certified by peer review) is the author/funder, who has granted medRxiv a license to display the preprint in perpetuity. It is made available under a CC-BY-NC-ND 4.0 International license .

Derr et al, preprint for medRxiv, 2020

N95 aHP decontamination study

765 SARS-CoV-2, no infectious virus was detected by TCID50 assay after aHP treatment. As in

766 Figure 2, multiple models of N95 respirator (see Table 1) were inoculated and either treated as

767 "drying only" controls (red), or subjected to aHP treatment (blue). The respirator surface and

768 model are indicated by the symbol shape and fill. The median of all points within a given aHP

769 cycle and treatment is indicated by a solid horizontal line. Viral titer was determined by tissue

770 culture infectious dose 50 (TCID50) assay in 96-well plates, with a limit of detection (LOD) of

7711.2 (see Methods for details). For the purposes of illustrating the decontaminated samples where

772 no virus was detected, these numbers were plotted as a value of 1. See Supplementary Table 1

773 for all data values. 
medRxiv preprint doi: https://doi.org/10.1101/2020.04.17.20068577; this version posted December 24, 2020. The copyright holder for this preprint (which was not certified by peer review) is the author/funder, who has granted medRxiv a license to display the preprint in perpetuity.

It is made available under a CC-BY-NC-ND 4.0 International license .

Derr et al, preprint for medRxiv, 2020

N95 aHP decontamination study

\section{References}

776 1. Rutala WA, Weber DJ, Healthcare Infection Control Practices Advisory Committee 777 (HICPAC). 2008. Guideline for Disinfection and Sterilization in Healthcare Facilities, 778 2008. Cent Dis Control CDC 163.

779 2. Centers for Disease Control and Prevention, National Center for Emerging and Zoonotic 780 Infectious Diseases (NCEZID), Division of Healthcare Quality Promotion (DHQP). 2008. 781 Guideline for Disinfection and Sterilization in Healthcare Facilities. Sterilizing Pract 782 Disinfect Steriliz Guidel Guidel Libr Infect Control CDC.

3. 3M Personal Safety Division. 2020. Disinfection of Filtering Facepiece Respirators. 3M Tech Bull 4.

4. Battelle Memorial Institute. 2016. Final Report for the Bioquell Hydrogen Peroxide Vapor (HPV) Decontamination for Reuse of N95 Respirators. Prep Contract - Study Number 3245 US Food Drug Adm 46.

5. Liao L, Xiao W, Zhao M, Yu X, Wang H, Wang Q, Chu S, Cui Y. 2020. Can N95

6. Schwartz A, Stiegel M, Greeson N, Vogel A, Thomann W, Brown M, Sempowski GD, and Reuse of N95 Respirators with Hydrogen Peroxide Vapor to Address Worldwide Personal Protective Equipment Shortages During the SARS-CoV-2 (COVID-19) Pandemic.

7. Goyal SM, Chander Y, Yezli S, Otter JA. 2014. Evaluating the virucidal efficacy of Appl Biosaf 25:67-70. peroxide vapour disinfection. J Hosp Infect 80:110-115. 
medRxiv preprint doi: https://doi.org/10.1101/2020.04.17.20068577; this version posted December 24, 2020. The copyright holder for this preprint (which was not certified by peer review) is the author/funder, who has granted medRxiv a license to display the preprint in perpetuity.

It is made available under a CC-BY-NC-ND 4.0 International license .

Derr et al, preprint for medRxiv, 2020

N95 aHP decontamination study

9. Holmdahl T, Odenholt I, Riesbeck K, Medstrand P, Widell A. 2019. Hydrogen peroxide vapour treatment inactivates norovirus but has limited effect on post-treatment viral RNA levels. Infect Dis 51:197-205.

10. Hultman C, Hill A, McDonnell G. 2006. The physical chemistry of decontamination with gaseous hydrogen peroxide. Pharm Eng 27:22-32.

11. Otter JA, Yezli S. 2011. A call for clarity when discussing hydrogen peroxide vapour and aerosol systems. J Hosp Infect 77:83-84.

12. Boyce JM. 2009. New Approaches to Decontamination of Rooms After Patients Are Discharged. Infect Control Hosp Epidemiol 30:515-517.

13. Fu TY, Gent P, Kumar V. 2012. Efficacy, efficiency and safety aspects of hydrogen peroxide vapour and aerosolized hydrogen peroxide room disinfection systems. J Hosp Infect 80:199-205.

14. Holmdahl T, Lanbeck P, Wullt M, Walder MH. 2011. A Head-to-Head Comparison of Hydrogen Peroxide Vapor and Aerosol Room Decontamination Systems. Infect Control Hosp Epidemiol 32:831-836.

15. Freyssenet C, Karlen S. 2019. Plasma-Activated Aerosolized Hydrogen Peroxide (aHP) in Surface Inactivation Procedures. Appl Biosaf 24:10-19.

16. Best EL, Parnell P, Thirkell G, Verity P, Copland M, Else P, Denton M, Hobson RP, Wilcox MH. 2014. Effectiveness of deep cleaning followed by hydrogen peroxide decontamination during high Clostridium difficile infection incidence. J Hosp Infect 87:25-33.

17. Barbut F, Menuet D, Verachten M, Girou E. 2009. Comparison of the Efficacy of a Hydrogen Peroxide Dry-Mist Disinfection System and Sodium Hypochlorite Solution for Eradication of Clostridium difficile Spores. Infect Control Hosp Epidemiol 30:507-514.

18. Shapey S, Machin K, Levi K, Boswell TC. 2008. Activity of a dry mist hydrogen peroxide system against environmental Clostridium difficile contamination in elderly care wards. J Hosp Infect 70:136-141. 
medRxiv preprint doi: https://doi.org/10.1101/2020.04.17.20068577; this version posted December 24, 2020. The copyright holder for this preprint (which was not certified by peer review) is the author/funder, who has granted medRxiv a license to display the preprint in perpetuity.

It is made available under a CC-BY-NC-ND 4.0 International license .

Derr et al, preprint for medRxiv, 2020

N95 aHP decontamination study

825

826

827

828

829

830

831

832

833

834

835

836

837

838

839

840

841

842

19. Bartels MD, Kristoffersen K, Slotsbjerg T, Rohde SM, Lundgren B, Westh H. 2008. Environmental meticillin-resistant Staphylococcus aureus (MRSA) disinfection using drymist-generated hydrogen peroxide. J Hosp Infect 70:35-41.

20. Andersen BM, Syversen G, Thoresen H, Rasch M, Hochlin K, Seljordslia B, Snevold I, Berg E. 2010. Failure of dry mist of hydrogen peroxide 5\% to kill Mycobacterium tuberculosis. J Hosp Infect 76:80-83.

21. Beswick AJ, Farrant J, Makison C, Gawn J, Frost G, Crook B, Pride J. 2011. Comparison of Multiple Systems for Laboratory Whole Room Fumigation. Appl Biosaf 16:139-157.

22. The National Institute for Occupational Safety and Health (NIOSH). 2020. Recommended Guidance for Extended Use and Limited Reuse of N95 Filtering Facepiece Respirators in Healthcare Settings. NIOSH Workplace Saf Health Top.

23. Hinton, Chief Scientist, Food and Drug Administration D. 2020. FDA Letter - Emergency Use Authorization (EUA) for the Battelle Critical Care Decontamination System (CCDS).

24. Schwartz A, Stiegel M, Greeson N, Vogel A, Thomann W, Brown M, Sempowski GD, Alderman TS, Condreay JP, Burch J, Wolfe C, Smith B, Lewis S. 2020. Decontamination and Reuse of N95 Respirators with Hydrogen Peroxide Vapor to Address Worldwide Personal Protective Equipment Shortages During the SARS-CoV-2 (COVID-19) Pandemic. Appl Biosaf 153567602091993.

25. Kenney P, Chan BK, Kortright K, Cintron M, Havill N, Russi M, Epright J, Lee L, Balcezak T, Martinello R. 2020. Hydrogen Peroxide Vapor sterilization of N95 respirators for reuse. medRxiv preprint.

26. Kumar A, Kasloff SB, Leung A, Cutts T, Strong JE, Hills K, Gu FX, Chen P, VazquezGrande G, Rush B, Lother S, Malo K, Zarychanski R, Krishnan J. 2020. Decontamination of N95 masks for re-use employing 7 widely available sterilization methods. PLOS ONE 15:e243965.

27. Levine C, Grady C, Block T, Hurley H, Russo R, Peixoto B, Frees A, Ruiz A, Alland D. 2021. Use, re-use or discard? Quantitatively defined variance in the functional integrity of 
medRxiv preprint doi: https://doi.org/10.1101/2020.04.17.20068577; this version posted December 24, 2020. The copyright holder for this preprint (which was not certified by peer review) is the author/funder, who has granted medRxiv a license to display the preprint in perpetuity.

It is made available under a CC-BY-NC-ND 4.0 International license .

Derr et al, preprint for medRxiv, 2020

N95 aHP decontamination study

852

853

854

855

856

857

858

859

860

861

862

863

864

865

866

867

868

869

870

871

872

873

874

875

876

N95 respirators following vaporized hydrogen peroxide decontamination during the COVID-19 pandemic. J Hosp Infect 107:50-56.

28. Fischer RJ, Morris DH, van Doremalen N, Sarchette S, Matson MJ, Bushmaker T, Yinda CK, Seifert SN, Gamble A, Williamson BN, Judson SD, de Wit E, Lloyd-Smith JO, Munster VJ. 2020. Effectiveness of N95 Respirator Decontamination and Reuse against SARS-CoV-2 Virus. Emerg Infect Dis 26:2253-2255.

29. Oral E, Wannomae KK, Connolly RL, Gardecki JA, Leung HM, Muratoglu OK, Durkin J, Jones R, Collins C, Gjore J, Budzilowicz A, Jaber T. 2020. Vaporized $\mathrm{H}_{2} \mathrm{O}_{2}$ decontamination against surrogate viruses for the reuse of N95 respirators in the COVID-19 emergency. preprint, Occupational and Environmental Health.

30. Grillet AM, Nemer MB, Storch S, Sanchez AL, Piekos ES, Leonard J, Hurwitz I, Perkins DJ. 2020. COVID-19 global pandemic planning: Performance and electret charge of N95 respirators after recommended decontamination methods. Exp Biol Med 153537022097638 .

31. Rockey N, Arts PJ, Li L, Harrison KR, Langenfeld K, Fitzsimmons WJ, Lauring AS, Love NG, Kaye KS, Raskin L, Roberts WW, Hegarty B, Wigginton KR. 2020. Humidity and Deposition Solution Play a Critical Role in Virus Inactivation by Heat Treatment of N95 Respirators. mSphere 5.

32. Occupational Safety and Health Administration (OSHA), United States Department of Labor. Limits for Air Contaminants. 19101000 TABLE Z-1 - TABLE Z-1.

33. American Conference of Governmental Industrial Hygienists (ACGIH). 2019. Hydrogen Peroxide: Threshold Limit Values (TLV) Chemical Substances, 7th ed. Cincinnati, OH.

34. Steris Healthcare. Biological Indicators for Sterilization | STERIS.

35. Advanced Chemical Sensors. AIHA-LAP ID No. 102047. Longwood, Florida.

36. SGS Galson Laboratories. AIHA-LAP ID No. 100324. E. Syracuse, New York 13057. 
medRxiv preprint doi: https://doi.org/10.1101/2020.04.17.20068577; this version posted December 24, 2020. The copyright holder for this preprint (which was not certified by peer review) is the author/funder, who has granted medRxiv a license to display the preprint in perpetuity.

It is made available under a CC-BY-NC-ND 4.0 International license .

Derr et al, preprint for medRxiv, 2020

N95 aHP decontamination study

877

878

879

880

881

882

883

884

885

886

887

888

889

890

891

892

893

894

895

896

897

898

899

900

901

37. Occupational Safety and Health Administration (OSHA), United States Department of Labor. Fit Testing Procedures (Mandatory). Respir Prot Stand 29 CFR 1910134 F - Fit Test Append Subpart B3 - Qual Fit-Test QLFT Protoc Saccharine Solut Aerosol Protoc Subpart C3 - Quant Fit-Test QNFT Protoc Ambient Aerosol Condens Nucl Count CNC Quant Fit Test Protoc. https://www.osha.gov/lawsregs/regulations/standardnumber/1910/1910.134AppA.

38. Operation and Service Manual. 2015. Portacount Pro 8030 and Portacount Pro+ 8038 Respirator Fit TestersRev. P. T.S.I., Inc., Shoreview, MN.

39. National Institute for Occupational Safety and Health. 2019. Determination of Particulate Filter Efficiency Level for N95 Series Filters Against Solid Particulates for Non-Powered, Air-Purifying Respirators Standard Testing Procedure (STP), p. 9. In TEB-APR-STEP0059Revision 3.2. https://www.cdc.gov/niosh/npptl/stps/apresp.html.

40. Hockett KL, Baltrus DA. 2017. Use of the Soft-agar Overlay Technique to Screen for Bacterially Produced Inhibitory Compounds. J Vis Exp https://doi.org/10.3791/55064.

41. Reed LJ, Muench H. 1938. A simple method of estimating fifty per cent endpoints. Am J Epidemiol 27:493-497.

42. 3M Personal Safety Division. $3 \mathrm{M}^{\mathrm{TM}}$ Aura ${ }^{\mathrm{TM}}$ Health Care Particulate Respirator and Surgical Mask $1870+$, N95.

43. Centers for Disease Control and Prevention (CDC). 2020. Implementing Filtering Facepiece Respirator (FFR) Reuse, Including Reuse after Decontamination, When There Are Known Shortages of N95 Respirators. Coronavirus Dis 2019 COVID-19.

44. van Doremalen N, Bushmaker T, Morris DH, Holbrook MG, Gamble A, Williamson BN, Tamin A, Harcourt JL, Thornburg NJ, Gerber SI, Lloyd-Smith JO, de Wit E, Munster VJ. 2020. Aerosol and Surface Stability of SARS-CoV-2 as Compared with SARS-CoV-1. N Engl J Med https://doi.org/10.1056/NEJMc2004973. 
medRxiv preprint doi: https://doi.org/10.1101/2020.04.17.20068577; this version posted December 24, 2020. The copyright holder for this preprint (which was not certified by peer review) is the author/funder, who has granted medRxiv a license to display the preprint in perpetuity.

It is made available under a CC-BY-NC-ND 4.0 International license .

Derr et al, preprint for medRxiv, 2020

N95 aHP decontamination study

902

903

904

905

906

907

908

909

910

911

912

913

914

915

916

917

918

919

920

921

922

923

45. Sizun J, Yu MWN, Talbot PJ. 2000. Survival of human coronaviruses 229E and OC43 in suspension and after drying onsurfaces: a possible source ofhospital-acquired infections. J Hosp Infect 46:55-60.

46. Duan S-M, Zhao X-S, Wen R-F, Huang J-J, Pi G-H, Zhang S-X, Han J, Bi S-L, Ruan L, Dong X-P, SARS Research Team. 2003. Stability of SARS coronavirus in human specimens and environment and its sensitivity to heating and UV irradiation. Biomed Environ Sci BES 16:246-255.

47. Rabenau HF, Cinatl J, Morgenstern B, Bauer G, Preiser W, Doerr HW. 2005. Stability and inactivation of SARS coronavirus. Med Microbiol Immunol (Berl) 194:1-6.

48. Geller C, Varbanov M, Duval R. 2012. Human Coronaviruses: Insights into Environmental Resistance and Its Influence on the Development of New Antiseptic Strategies. Viruses 4:3044-3068.

49. Firquet S, Beaujard S, Lobert P-E, Sané F, Caloone D, Izard D, Hober D. 2015. Survival of Enveloped and Non-Enveloped Viruses on Inanimate Surfaces. Microbes Environ 30:140144.

50. Kampf G, Todt D, Pfaender S, Steinmann E. 2020. Persistence of coronaviruses on inanimate surfaces and their inactivation with biocidal agents. J Hosp Infect 104:246-251.

51. Vasickova P, Pavlik I, Verani M, Carducci A. 2010. Issues Concerning Survival of Viruses on Surfaces. Food Environ Virol 2:24-34. 
medRxiv preprint doi: https://doi.org/10.1101/2020.04.17.20068577; this version posted December 24, 2020. The copyright holder for this preprint (which was not certified by peer review) is the author/funder, who has granted medRxiv a license to display the preprint in perpetuity.

It is made available under a CC-BY-NC-ND 4.0 International license .

Derr et al, preprint for medRxiv, 2020

N95 aHP decontamination study

\section{Supplementary Figures}

925

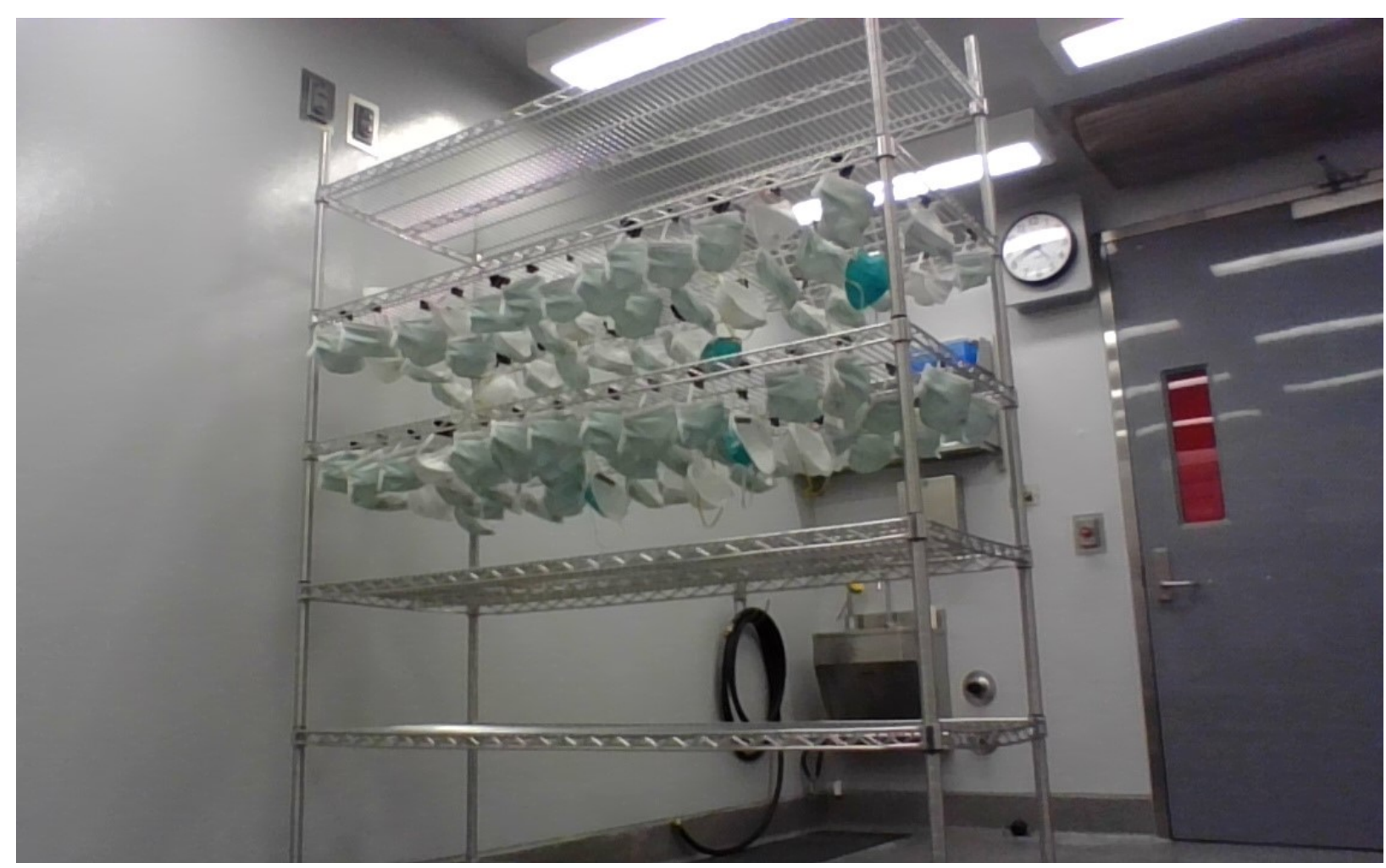

\section{Supplementary Figure 1: Respirators positioned on rack}

928 Respirator staging (partial loading) on metal rack with binder clips and rack centrally positioned 929 in the Prep Room. 
medRxiv preprint doi: https://doi.org/10.1101/2020.04.17.20068577; this version posted December 24, 2020. The copyright holder for this preprint (which was not certified by peer review) is the author/funder, who has granted medRxiv a license to display the preprint in perpetuity.

It is made available under a CC-BY-NC-ND 4.0 International license .

Derr et al, preprint for medRxiv, 2020

N95 aHP decontamination study

931
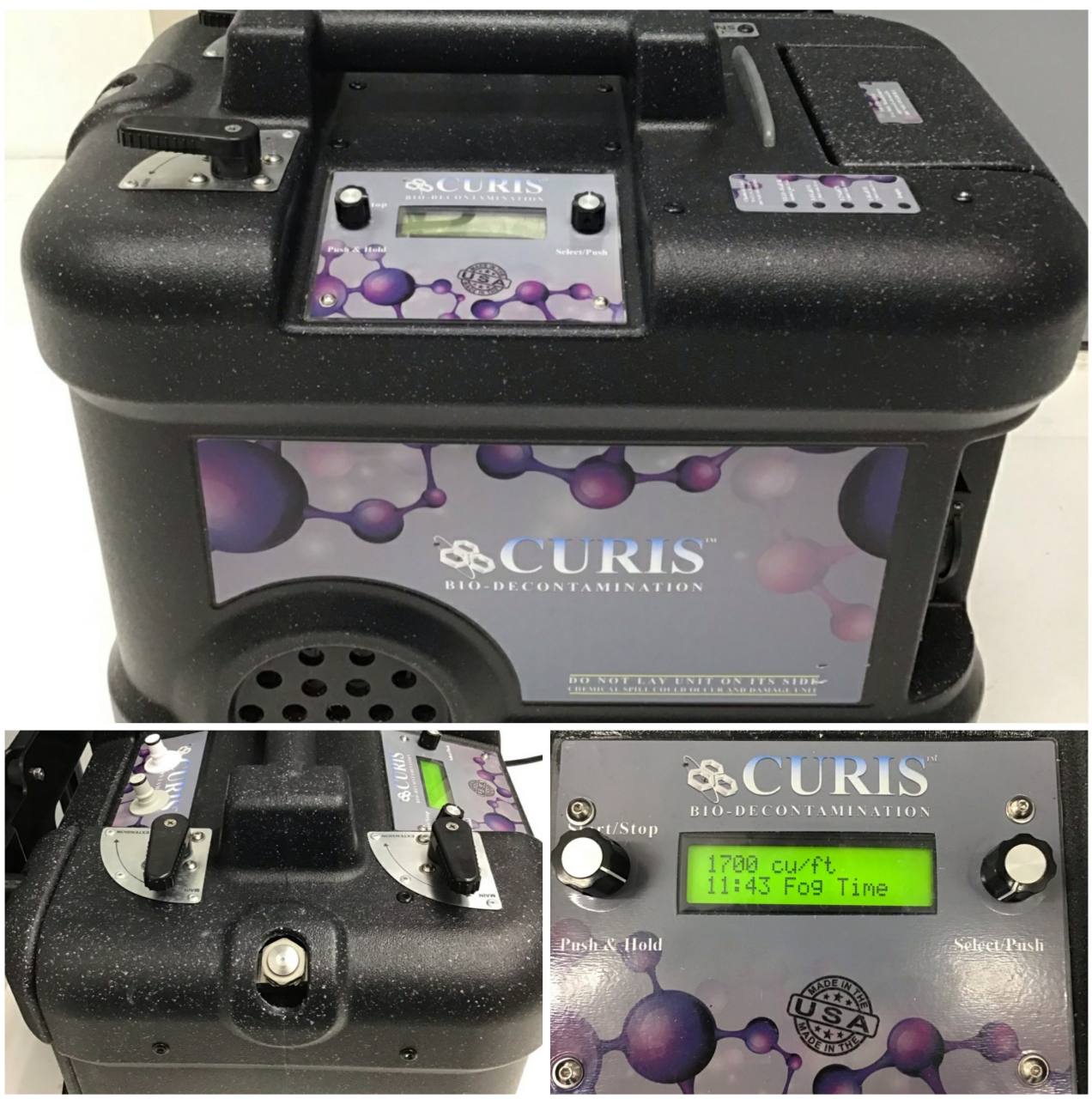

933 Supplementary Figure 2: Curis $^{\circledR}$ unit.

934 Curis $^{\circledR}$ decontamination unit with adjustable aHP dispersal nozzle and programmable inputs. 
medRxiv preprint doi: https://doi.org/10.1101/2020.04.17.20068577; this version posted December 24, 2020. The copyright holder for this preprint (which was not certified by peer review) is the author/funder, who has granted medRxiv a license to display the preprint in perpetuity.

It is made available under a CC-BY-NC-ND 4.0 International license .

Derr et al, preprint for medRxiv, 2020

N95 aHP decontamination study

936

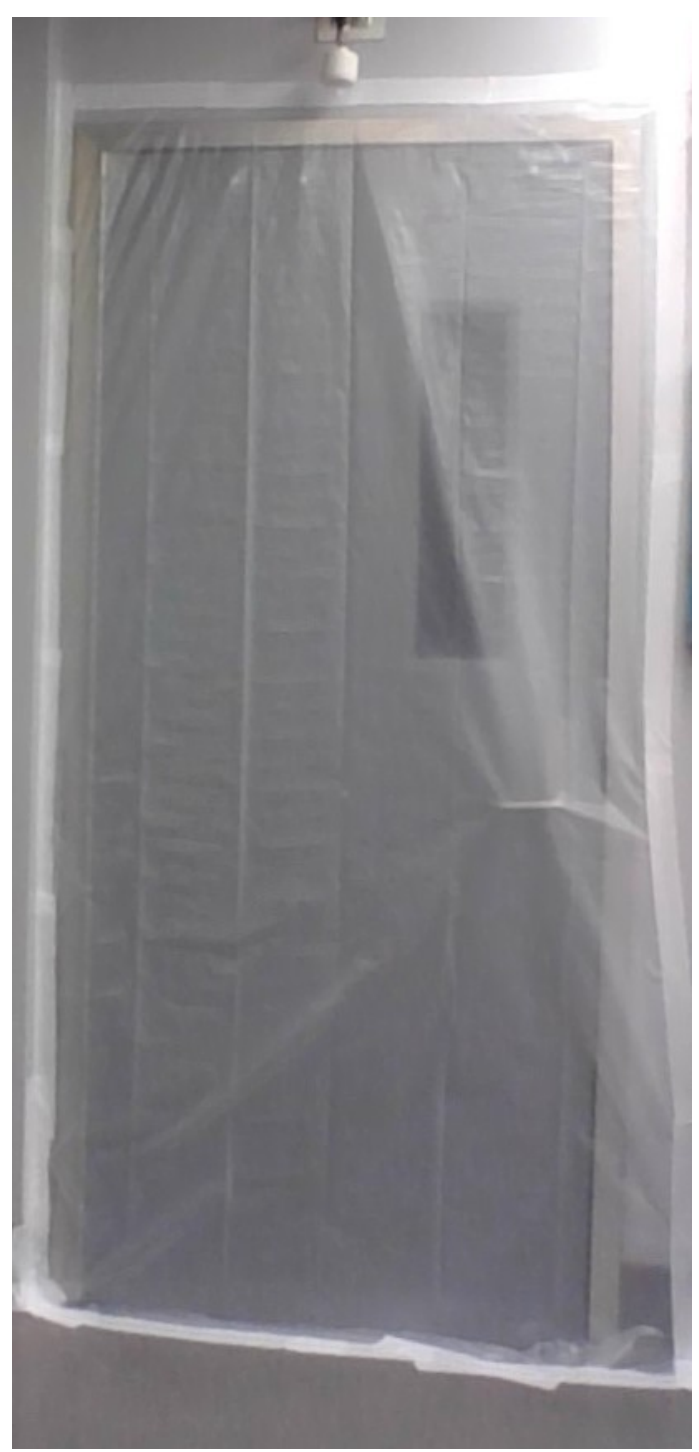

938 Supplementary Figure 3: Prep Room door seal

939 Door sealed with polyethylene sheeting and non-porous adhesive tape to prevent migration of $940 \quad \mathrm{H}_{2} \mathrm{O}_{2}$ outside of the Prep Room.

941 
medRxiv preprint doi: https://doi.org/10.1101/2020.04.17.20068577; this version posted December 24, 2020. The copyright holder for this preprint (which was not certified by peer review) is the author/funder, who has granted medRxiv a license to display the preprint in perpetuity.

It is made available under a CC-BY-NC-ND 4.0 International license .

Derr et al, preprint for medRxiv, 2020

N95 aHP decontamination study
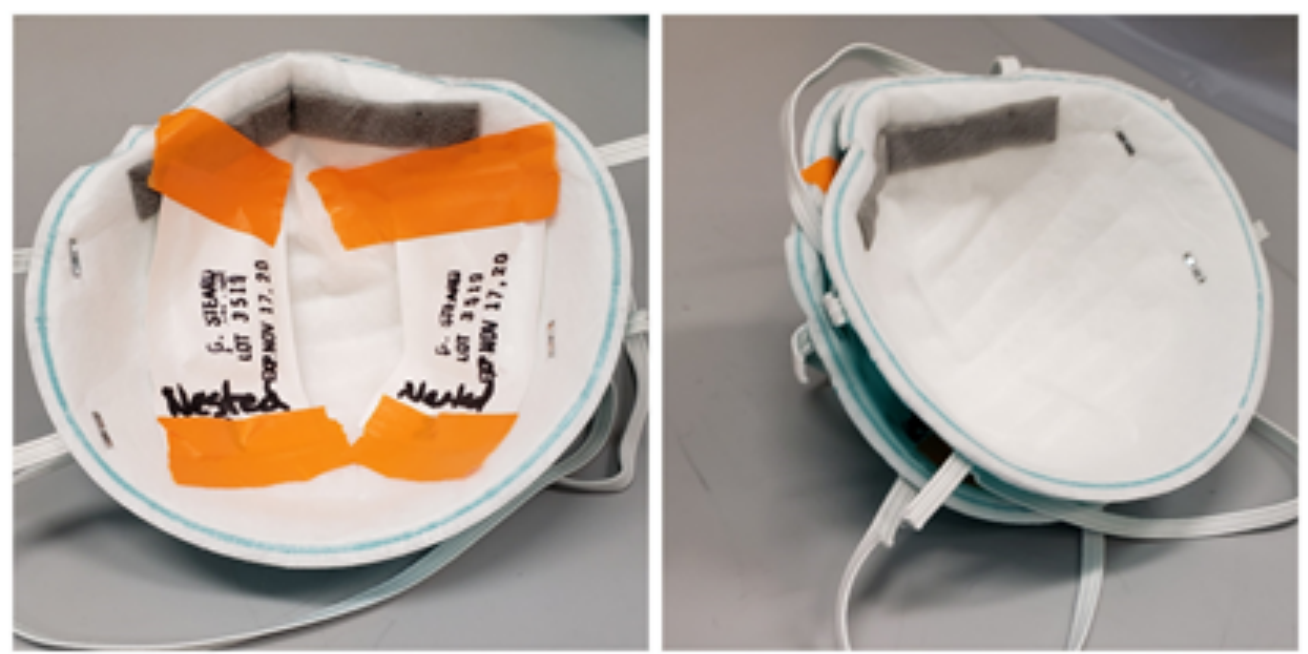

\section{Supplementary Figure 4: BIs positioned within nested N95 respirators}

945 In order to test the ability of aHP under these cycle parameters to penetrate respirator material,

946 biological indicators (BI's) (Geobacillius stearothermophilis) were nested between two molded

947 respirators (3M 1860) and taped together, or BIs were enclosed within a flat-fold type respirator

948 (3M Aura 9211+; not pictured). All BIs positioned in this manner were rendered inactivated after

949 aHP treatment. 
medRxiv preprint doi: https://doi.org/10.1101/2020.04.17.20068577; this version posted December 24, 2020. The copyright holder for this preprint (which was not certified by peer review) is the author/funder, who has granted medRxiv a license to display the preprint in perpetuity.

It is made available under a CC-BY-NC-ND 4.0 International license .

Derr et al, preprint for medRxiv, 2020

N95 aHP decontamination study
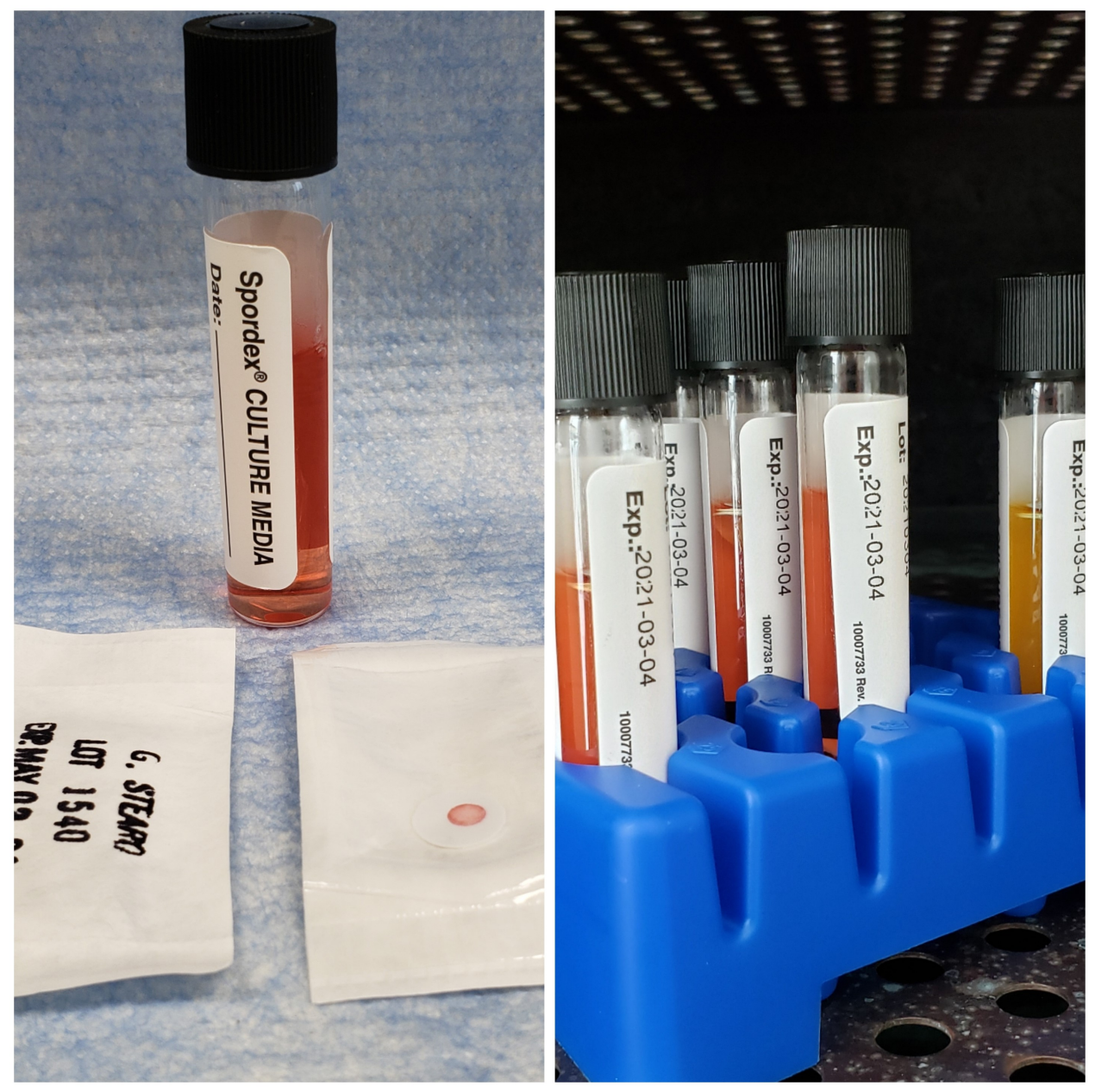

953 Supplementary Figure 5: Cultures of spore-based biological indicators

954 Biological indicator spore discs are transferred from Tyvek/glassine envelopes to culture media

955 and incubated for at $55^{\circ} \mathrm{C}$ for at least 7 days post decontamination cycle. Media color change to

956 yellow indicates bacterial growth, as seen in the positive control tube on the far right. 
medRxiv preprint doi: https://doi.org/10.1101/2020.04.17.20068577; this version posted December 24, 2020. The copyright holder for this preprint (which was not certified by peer review) is the author/funder, who has granted medRxiv a license to display the preprint in perpetuity.

It is made available under a CC-BY-NC-ND 4.0 International license .

Derr et al, preprint for medRxiv, 2020

N95 aHP decontamination study

958

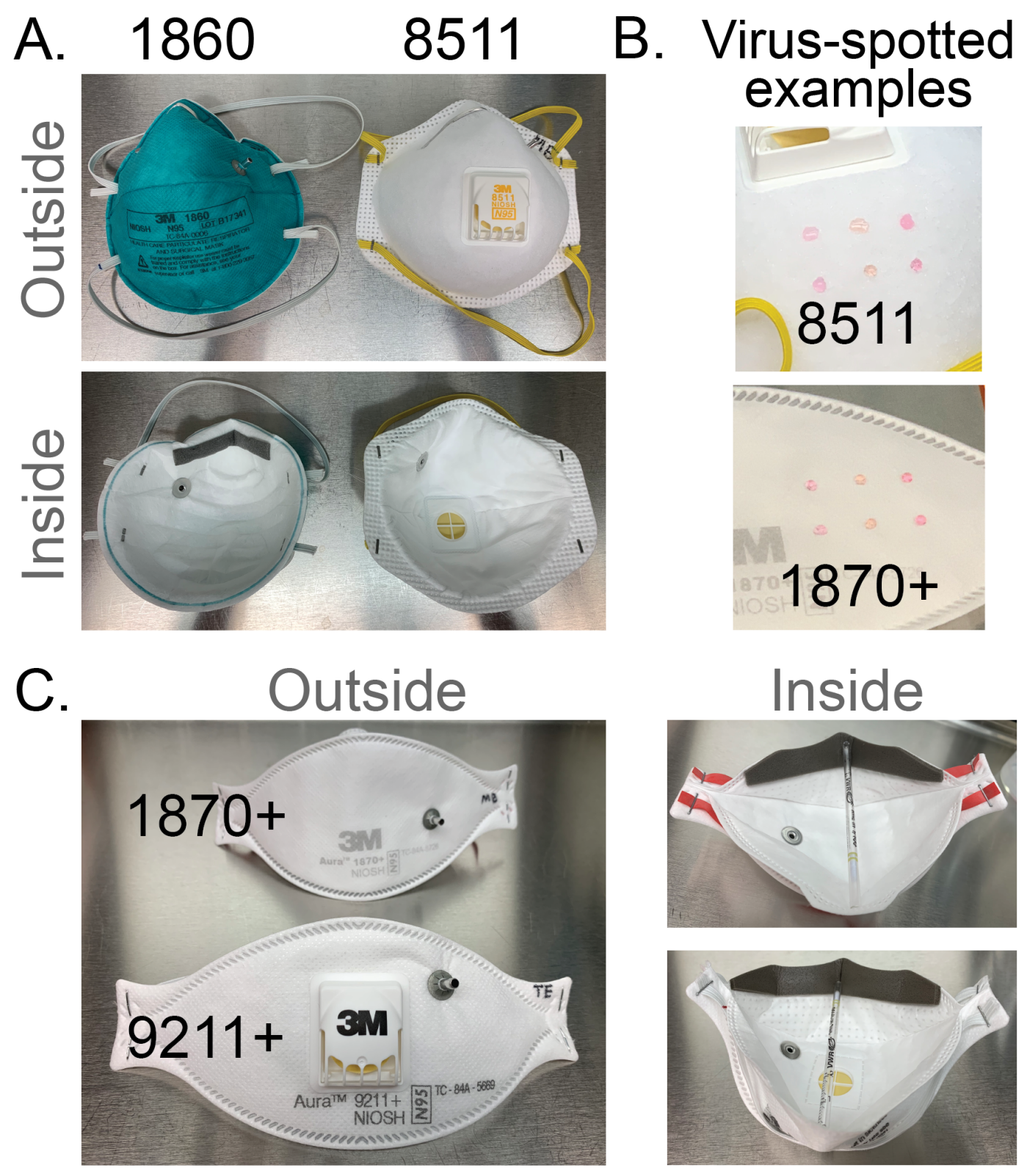

960 Supplementary Figure 6: Respirator facepiece models \& characteristics

961 (A) 3M models 1860 and 8511 (left) have a molded facepiece, with 8511 including an exhalation

962 valve. (B) Virus-inoculation via droplets spotted onto the respirator fabric are shown for two

963 examples. (C) 3M models 1870+ and 9211+ share a common folded fabric model, with a high

964 fluid resistance of the fabric. 3M 9211+ includes an exhalation valve. Several of the facepieces

$965(1860,1870+, 9211+)$ display the metal grommet from insertion of the probe used for

966 quantitative fit testing (QNFT). The inner face of each respirator is shown, which for the models

967 shown in (C) required a prop to hold them open. 
medRxiv preprint doi: https://doi.org/10.1101/2020.04.17.20068577; this version posted December 24, 2020. The copyright holder for this preprint (which was not certified by peer review) is the author/funder, who has granted medRxiv a license to display the preprint in perpetuity.

It is made available under a CC-BY-NC-ND 4.0 International license .

Derr et al, preprint for medRxiv, 2020

N95 aHP decontamination study

968

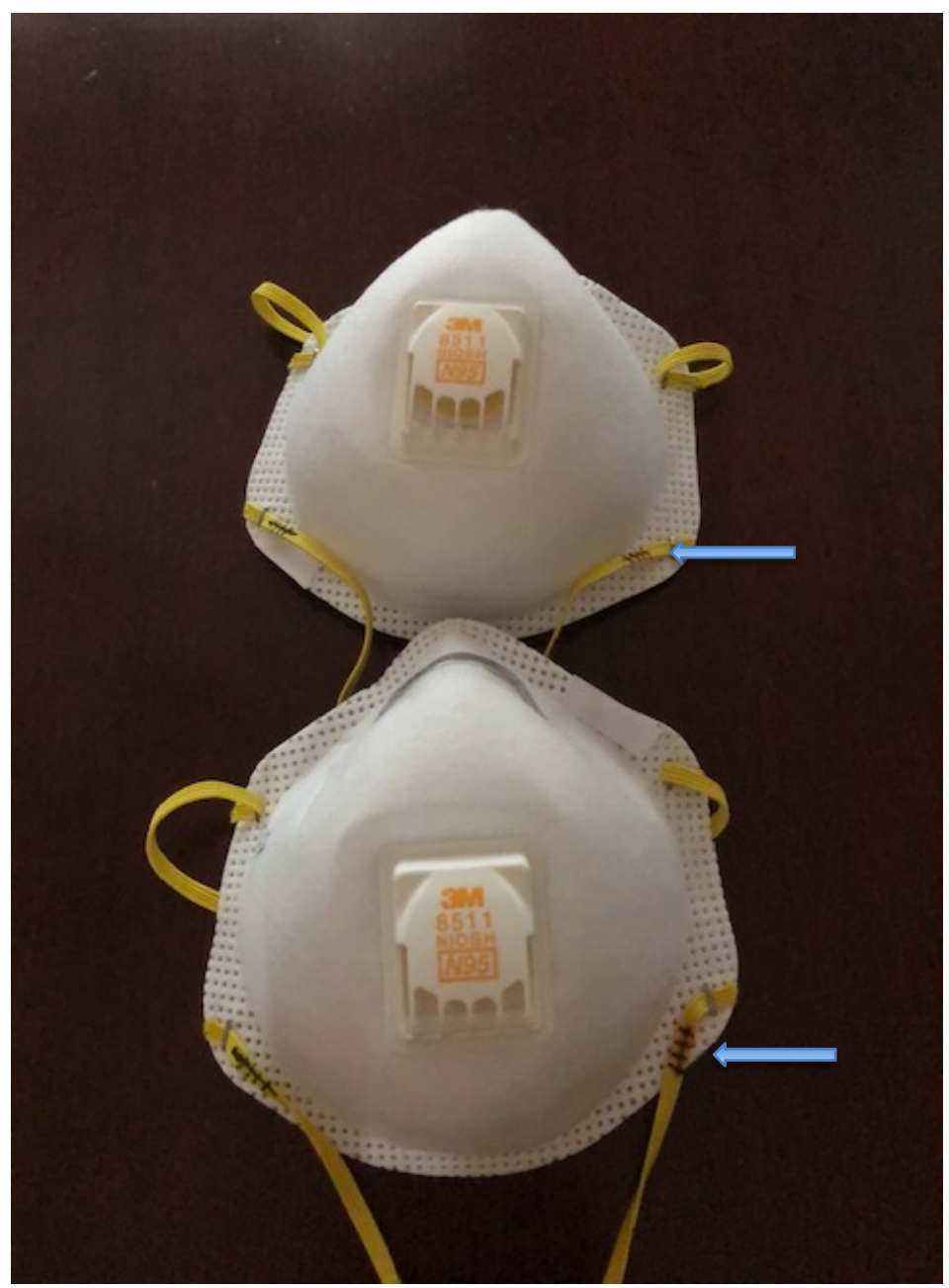

970 Supplementary Figure 7: Respirator aHP cycle markings

971 Indelible ink pen hash marks (noted at lower respirator straps) placed to notate completed aHP

972 cycle, at time of cycle completion, or collection/transport for subsequent fit-testing or virus

973 inactivation testing.

974 
medRxiv preprint doi: https://doi.org/10.1101/2020.04.17.20068577; this version posted December 24, 2020. The copyright holder for this preprint (which was not certified by peer review) is the author/funder, who has granted medRxiv a license to display the preprint in perpetuity.

It is made available under a CC-BY-NC-ND 4.0 International license .

Derr et al, preprint for medRxiv, 2020

N95 aHP decontamination study

975

976

A.

$1: 1000$

$1: 100$

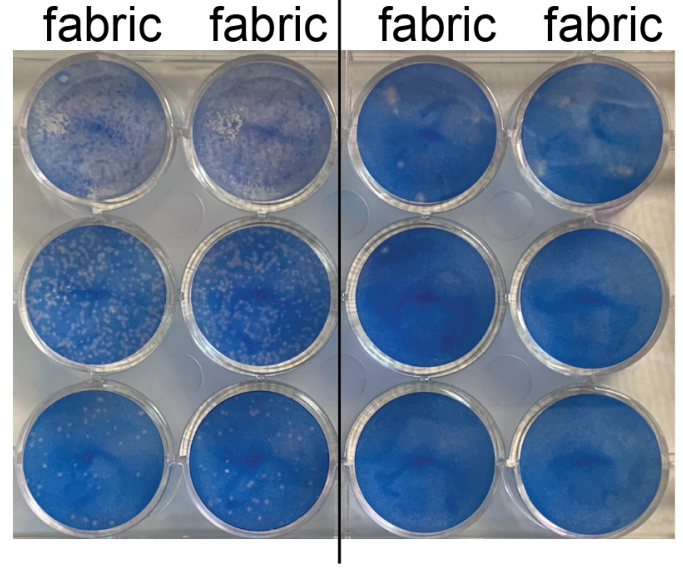

B.

HSV-1

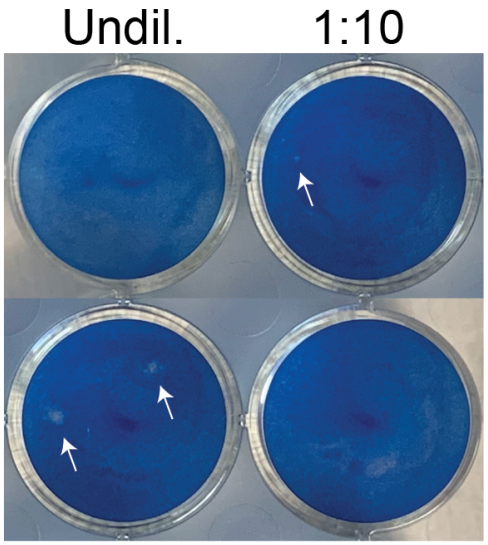

977 Supplementary Figure 8: Viral titration demonstrates inactivation and loss of infectious units due to drying and aerosolized $\mathrm{H}_{2} \mathrm{O}_{2}$ (aHP) decontamination

979 Shown here are representative examples of serial dilutions (titration) of HSV-1 or CVB3 that

980 were spotted onto 3M 9211+ respirators, and then resuspended and plated onto monolayers of

981 Vero detector cells. Viral plaques, which are visible as clear foci of infection (plaque-forming

982 units, or PFU) on the background of methylene blue-stained cells, were visualized at 72 hours

983 post infection. The plate shown in (A) illustrates serial dilution of a high concentration of HSV-1

984 after drying ( $10^{5} \mathrm{PFU}$; see plot in Figure 3A), and a lower concentration of CVB3 after drying

985 (102 PFU; see plot in Figure 4A). The plate shown in (B) is from an aHP cycle run with

986 "Modification 1" parameters, when no dwell time was used (aHP cycle 3; see Tables 3-4) and

987 commercial spore-based biological indicators indicated a failure of decontamination. Even on

988 this partial aHP decontamination, only three wells (of which two are shown above) had any viral

989 plaques (indicated by arrowheads; these equate to 25 PFU of HSV-1, and 5 PFU of CVB3; see

990 plots in Figure 3A and 4A).

991 
medRxiv preprint doi: https://doi.org/10.1101/2020.04.17.20068577; this version posted December 24, 2020. The copyright holder for this preprint (which was not certified by peer review) is the author/funder, who has granted medRxiv a license to display the preprint in perpetuity.

It is made available under a CC-BY-NC-ND 4.0 International license .

Derr et al, preprint for medRxiv, 2020

N95 aHP decontamination study

\section{Supplementary Table (separate Excel file)}

\section{Supplementary Table 1 (Excel): aHP Viral Testing Values}

994 Data underlying Figures 2-4, and Table 4. These include the number of plaque-forming units 995 (PFU) for phi6, HSV-1, and CVB3, as well as TCID50 $(\log 10) / \mathrm{mL}$ values for SARS-CoV-2. As

996 noted in Figures 2-4, for samples where no virus was detected, these numbers were replaced with

997 non-zero values to allow their visualization on the log-scale plots in Figures 2-4. HSV-1, CVB3,

998 and phi6 "no virus detected" values were set to 0.5 (less than 1 plaque detected), and SARS-

999 CoV-2 values were set to 1 (less than the limit of detection of 1.2 TCID50( $\log 10) / \mathrm{mL}$ ). 